\title{
Future directions in the diagnosis and medical treatment of adrenocortical carcinoma
}

\author{
S G Creemers ${ }^{1,2}$, L J Hofland ${ }^{1,2}$, E Korpershoek ${ }^{1,3}$, G J H Franssen ${ }^{1,4}$, \\ F J van Kemenade ${ }^{1,3}$, W W de Herder ${ }^{1,2}$ and R A Feelders ${ }^{1,2}$
}

${ }^{1}$ Rotterdam Adrenal Center, Erasmus MC University Medical Center, Rotterdam, The Netherlands ${ }^{2}$ Department of Internal Medicine, Division of Endocrinology, Erasmus MC University Medical Center, Rotterdam, The Netherlands

${ }^{3}$ Department of Pathology, Erasmus MC University Medical Center, Rotterdam, The Netherlands

${ }^{4}$ Department of Surgery, Erasmus MC University Medical Center, Rotterdam, The Netherlands
Correspondence

should be addressed

to R A Feelders

Email

r.feelders@erasmusmc.nl

\begin{abstract}
Adrenocortical carcinoma (ACC) is a rare disease with a poor prognosis. Discrimination between ACCs and adrenocortical adenomas (ACAs) remains challenging, with the current gold standard being the Weiss score, consisting of several histopathological characteristics. However, new markers like Ki67, a marker for proliferation, and the staining of reticulins are promising not only as it comes to identifying malignancy but also as prognostic markers in patients with ACC. Currently, surgery is still the only curative treatment for ACC. Mitotane, an adrenolytic drug, is used in the adjuvant setting and in case of metastatic or advanced disease. Patients with progressive disease are frequently treated with mitotane, alone or in combination with etoposide, doxorubicine and cisplatin. Radiotherapy is indicated in selected cases. The low response rates and high toxicity of the systemic therapies emphasize the need for markers that enable the identification of responders and non-responders. Consequently, research is focusing on predictive factors varying from the expression of DNA repair genes to clinical patient characteristics. Subgroups of ACC with different prognosis have been identified based on transcriptome characteristics. As a conclusion from large molecular studies, ACCs appear to harbor many abnormalities compared to ACAs. Altered pathways driving ACC pathogenesis include the IGF, TP53 and the Wnt signaling pathway, allowing these as new potential targets for medical therapy. However, despite efforts in preclinical and clinical studies investigating efficacy of targeting these pathways, most novel therapies appear to be effective in only a subset of patients with ACC. New treatment concepts are therefore urgently needed.
\end{abstract}

Key Words

\section{Introduction}

Adrenocortical carcinoma (ACC) is an aggressive but rare malignancy with an incidence of 0.5 to 2 cases per million per year (Kebebew et al. 2006, Golden et al. 2009, Fassnacht et al. 2013, Kerkhofs et al. 2013b). Five-year survival rates

vary from 16 to $40 \%$ and are largely dependent on the ACC stage at diagnosis (Fassnacht et al. 2009, 2010). Most ACCs occur sporadically, but ACCs can also be associated with various genetic syndromes, e.g. Li Fraumeni syndrome

Published by Bioscientifica Ltd
Endocrine-Related Cancer

(2016) 23, R43-R69 
(Kleihues et al. 1997, Birch et al. 2001, Gonzalez et al. 2009), Beckwith-Wiedemann syndrome (BWS) (Wiedemann 1983, Steenman et al. 2000, Lapunzina 2005), multiple endocrine neoplasia type 1 (MEN1) (Waldmann et al. 2007, Gatta-Cherifi et al. 2012) and Lynch syndrome (Medina-Arana et al. 2011, Karamurzin et al. 2012, Raymond et al. 2013). To a lesser extent, ACC can be associated with familial adenomatous polyposis (Gaujoux et al. 2010), neurofibromatosis type 1 (Wagner et al. 2005) and Werner syndrome (Takazawa et al. 2004). Despite much effort to improve care for patients with ACC, diagnosis and treatment still have limited opportunities. A better understanding of the pathogenesis and the identification of potential new therapeutic targets could lead to a more personalized approach in patients with ACC. Furthermore, it should be emphasized that ACC patients should only be referred to specialized centers that have extensive experience in the management of this rare cancer (Lacroix 2010). In this review, we provide an overview of the current diagnostic opportunities and challenges in ACC, and focus on the therapeutic strategies and targets for therapy. We describe the current standard care as well as perspectives for future directions based on findings from basic science and clinical research.

\section{Diagnosis of ACCs}

\section{Current tools to diagnose ACCs}

Imaging A thorough preoperative diagnostic work up is essential in patients with an (incidentally discovered) adrenal mass to differentiate between ACC and adrenocortical adenoma (ACA) (Lacroix 2010). Initial assessment of malignancy risk is predominantly performed by the evaluation of radiological characteristics on (contrast-enhanced) CT or MRI (Nieman 2010). Most patients with ACC present with large tumors, measuring more than $6 \mathrm{~cm}$ in diameter, but with local disease (Schulick \& Brennan 1999, Icard et al. 2001, Boland et al. 2008, Johnson et al. 2009).

Other CT characteristics that (to a certain extent) discriminate between ACCs and ACAs include lack of a well-defined margin, increased heterogeneity, central low attenuation, calcifications, and extension into the inferior vena cava (Nieman 2010, Zhang et al. 2012). On contrast enhanced CT a high contrast washout and >10 Hounsfield Units (HU) are characteristic for malignancy. Size is thought to be the most important predictor for malignancy, with an increase from 52 to $80 \%$ specificity for malignancy for tumors larger than $4-6 \mathrm{~cm}$ respectively (Sturgeon et al. 2006). In the largest series on adrenal imaging so far, Petersenn et al. (2015) suggest that a threshold of $13 \mathrm{HU}$ instead of $10 \mathrm{HU}$ should be used to more adequately diagnose ACC. If the characteristics on unenhanced CT followed by contrast-enhanced examinations do not show a classic ACC appearance, MRI can provide additional information regarding the diagnosis (Ilias et al. 2007). Although these findings together will not always indicate a clear diagnosis, the previously mentioned characteristics on a CT scan are currently used to guide the decision on adrenalectomy. Adrenalectomy is generally performed in case of lesions larger than $4 \mathrm{~cm}$ (Petersenn et al. 2015).

In 2011, a systematic review included 21 studies which investigated the value of $18 \mathrm{~F}$-fluorodeoxyglucose positron emission tomography ( ${ }^{18}$ F-FDG PET) to differentiate benign from malignant adrenal tumors (Boland et al. 2011). In 1217 patients, a mean sensitivity of $97 \%$ and a specificity of $91 \%$ was found. No differences were found between ${ }^{18}$ F-FDG PET and ${ }^{18}$ F-FDG PET/CT. After this systematic review, several other studies were performed confirming the high sensitivity and negative predictive value for diagnosing ACCs. Also, it is reported that ${ }^{18}$ F-FDG PET and CT can be complementary as it comes to initial diagnosis of ACC and recurrence detection (Leboulleux et al. 2006, Nunes et al. 2010, Gust et al. 2012). Important considerations that should be taken into account with the ${ }^{18}$ F-FDG PET(/CT) scans are the increased uptake seen in case of an adrenal metastasis or in several benign conditions. Furthermore, ${ }^{18} \mathrm{~F}$-FDG PET(/CT) is considered less sensitive and specific for characterizing smaller lesions $(<1 \mathrm{~cm})$ and ${ }^{18}$ F-FDG uptake can also be increased in the contralateral adrenal after adrenalectomy following mitotane treatment (Leboulleux et al. 2011). Recently, a retrospective study $(n=106)$ showed that only for a minority $(\sim 5 \%)$ of patients undergoing ${ }^{18}$ F-FDG PET/CT, the scan would have changed the clinical management at initial staging (Takeuchi et al. 2014). In case of chemotherapy, PET/CT could predict response earlier than the detection of anatomic changes on CT (Takeuchi et al. 2014). Up to this moment, there are equivocal findings as it comes to ${ }^{18} \mathrm{~F}-\mathrm{FDG}$ PET/CT measurements as a prognostic marker, probably because of the low number of patients included in the studies.

Staging The ENSAT-staging, a reclassification of the Union for International Cancer Control staging system, is the system currently used for staging of adrenal tumors (Table 1; Fassnacht et al. 2009, Lughezzani et al. 2010). The staging is based on the evaluation of a total of 1065 patients with ACC. Recently, Asare et al. (2014) reported

Published by Bioscientifica Ltd. 
Table 1 Staging system for ACCs

\begin{tabular}{|c|c|c|c|}
\hline ENSAT stage & $\mathbf{T}$ & $\mathbf{N}$ & $\mathbf{M}$ \\
\hline I & 1 & 0 & 0 \\
\hline II & 2 & 0 & 0 \\
\hline \multirow[t]{2}{*}{ III } & 1,2 & 1 & 0 \\
\hline & 3,4 & 0,1 & 0 \\
\hline IV & $1-4$ & 0,1 & 1 \\
\hline
\end{tabular}

ENSAT, European Network for the Study of Adrenal Tumors. Tumors are classified as follows: T1, tumor $\leq 5 \mathrm{~cm}$; T2, tumor $>5 \mathrm{~cm}$; T3, tumor infiltration into surrounding (fat) tissue; T4, tumor invasion into adjacent organs or venous tumor thrombus in vena cava or renal vein; N0, no spread into nearby lymph nodes; N1, positive lymph node(s); M0, no distant metastasis; M1, presence of distant metastasis.

that predicting 5-year overall survival rates in patients with stage I/II ACC would improve if patient age is added to the ENSAT staging.

Biochemistry Patients with ACC often present with symptoms due to hormonal overproduction (40-60\% of cases, of which $50-80 \%$ are due to hypercortisolism). Patients without hormone overproduction present with nonspecific symptoms due to local tumor growth or spread of tumor to surrounding or distant tissues (Allolio \& Fassnacht 2006, Fassnacht \& Allolio 2009). Biochemical evaluation, which is in part guided by hormone-related clinical symptoms of patients, is performed by measurement of steroid hormones potentially produced by the tumor. For several reasons it is important to perform biochemical evaluation prior to surgery (Nieman 2010): i) it can further add to judge the risk of malignancy, since this risk increases in case of androgen or estrogen production; ii) in case of glucocorticoid excess cortisol lowering- or antagonizing therapy can be indicated; iii) patients with cortisol producing ACCs need hydrocortisone replacement post-surgery; iv) hormonal parameters can be used as tumor markers; v) pre-surgical testing for pheochromocytoma-related hormones can avoid complications during surgery (Song et al. 2011).

Pathology The Weiss score (WS) is currently the most widely used classification system for the pathological assessment of adrenocortical tumors (Weiss 1984, Lau \& Weiss 2009). It consists of nine morphological parameters and since 1989 a threshold for malignancy of at least three criteria present in the tumor (Weiss et al. 1989). Different more simplified algorithms have been proposed with only the most reliable parameters included (Aubert et al. 2002). Pennanen et al. (2015) recently developed the Helsinki score, which consists of the sum of $3 \times$ mitotic rate $+5 \times$ presence of necrosis + maximum proliferation index.
This scoring system was able to diagnose metastatic ACC with $100 \%$ sensitivity and $99.4 \%$ specificity, whereas the revised WS of Aubert et al. had a sensitivity of $100 \%$ and specificity of $96.9 \%$. The WS lacks reproducibility and is difficult to apply in ACC variants and pediatric adrenocortical tumors. The reliability of the WS is challenged in borderline cases, where a WS of 2 can be suggestive for an ACC (Tissier et al. 2012, Papotti et al. 2014). To prevent overdiagnosis in oncocytic variants with the classic WS, an alternative diagnostic system was proposed (Bisceglia et al. 2004) and also validated to correctly predict malignancy in this ACC variant (Wong et al. 2011). ACCs can also be classified as myxoid, sarcomatoid or mixed variants. Because of the remaining difficulties with the WS and the Lin-Weiss-Bisceglia system, and because only a definite diagnosis can be made in the presence of metastasis, pathologists have put effort in developing new techniques to refine the diagnostic assessment of adrenal tumors.

Ki67, a marker for proliferation, has raised attention for its use in the differential diagnosis of adrenal tumors (Table 2). The monoclonal antibody MIB1, which reacts with Ki67, is used for immunohistochemistry (Cattoretti et al. 1992). Ki67 evaluation seems to be reproducible, with intra- and inter-observer differences of 3.7 and $4.2 \%$ respectively (Morimoto et al. 2008). The general agreement is that ACCs have a Ki67 labeling index of $\geq 5 \%$. In a large study ( $n=319$, validation cohort $n=250$; all patients after complete resection of the tumor) evaluating the prognostic value of histopathological, clinical and immunohistochemical markers, Ki67 alone most powerfully predicted recurrence-free and overall survival (Fig. 1, Beuschlein et al. 2015). In addition, the authors recommend that based on their results Ki67 should be introduced in the routine pathology for adrenocortical tumors.

Volante et al. (2009) demonstrated that disruption of reticular networks, defined as the loss of continuity of reticular fibres or basal membrane network as highlighted by histochemical staining, was present in all ACCs included in their study ( $n=92$; Table 2$)$. By adding at least one of the following three parameters - necrosis, high mitotic rate or vascular invasion - this reticulin algorithm identified malignancy with a sensitivity and specificity of $100 \%$ (Volante et al. 2009). A study aiming to validate especially the first part of the algorithm, the presence of reticulin fibre disruptive changes, in 178 adrenocortical tumors, showed that a specific training increased the interobserver reproducibility to $86 \%$ (Duregon et al. 2013a). Specifically for cortical tumor variants like oncocytic and myxoid subtypes this algorithm might be

Published by Bioscientifica Ltd 
Table 2 Overview of the diagnostic value of the IGF2 gene, the proliferation marker Ki67, and the staining of reticulins to discriminate ACCs from ACAs. Only studies which analyzed the discriminative value of the molecular markers were included in this overview. Total sensitivity and specificity represents a weighted mean

\begin{tabular}{|c|c|c|c|c|c|c|c|}
\hline Study & $\operatorname{ACC}(n)$ & ACA $(n)$ & Sens $(\%)$ & Spec $(\%)$ & Cutoff & Reference diagnosis & Comments \\
\hline \multicolumn{8}{|l|}{ IGF2 } \\
\hline Gicquel et al. (1994) & 6 & 17 & 83 & 88 & $\begin{array}{l}\text { IGF2 mRNA > } 100 \\
\text { times that in normal } \\
\text { adrenals }\end{array}$ & $\begin{array}{l}\text { Clinical data, CT and } \\
\text { pathology }\end{array}$ & \\
\hline Gicquel et al. (1997) & 18 & 35 & 61 & 91 & $\begin{array}{l}\text { Presence of } 11 \mathrm{p} 13-15 \\
\text { LOH }\end{array}$ & Histological features & \\
\hline Gicquel et al. (1997) & 29 & 35 & 86 & 100 & $\begin{array}{l}\text { IGF2 mRNA }>10-582 \\
\text { times that in normal } \\
\text { adrenals }\end{array}$ & Histological features & \\
\hline Erickson et al. (2001) & 67 & 64 & 93 & 45 & Positive IGF2 IHC & NR & \\
\hline Schmitt et al. (2006) & 17 & 22 & 76 & 100 & Positive IGF2 IHC & $\begin{array}{l}\text { WS, Hough and } \\
\text { van Slooten }\end{array}$ & \\
\hline Soon et al. (2009a) & 23 & 41 & 78 & 100 & Positive IGF2 IHC & WS & \\
\hline Wang et al. (2014) & 25 & 25 & 64 & 72 & Positive IGF2 IHC & $\begin{array}{l}\text { WS and clinical and } \\
\text { biochemical data }\end{array}$ & \\
\hline Total & 185 & 239 & 81 & 80 & & & \\
\hline \multicolumn{8}{|l|}{ Ki67 } \\
\hline lino et al. (1997) & 17 & 28 & 65 & 100 & $\mathrm{LI}>2.5$ & NR & \\
\hline Vargas et al. (1997) & 20 & 20 & 95 & 100 & TPF $>80$ & WS & \\
\hline Wachenfeld et al. (2001) & 8 & 26 & 75 & 81 & $\mathrm{LI} \geq 5$ & WS and clinical data & \\
\hline Terzolo et al. (2001) & 11 & 26 & 100 & 100 & TPF $>70-90$ & WS & \\
\hline Schmitt et al. (2006) & 16 & 22 & 88 & 95 & $\mathrm{LI} \geq 5 \%$ & $\begin{array}{l}\text { WS, Hough and } \\
\text { van Slooten }\end{array}$ & \\
\hline Soon et al. (2009a) & 23 & 41 & 70 & 100 & $\mathrm{LI} \geq 5 \%$ & WS & \\
\hline Wang et al. (2014) & 25 & 25 & 64 & 96 & $\mathrm{LI} \geq 5 \%$ & $\begin{array}{l}\text { WS and clinical and } \\
\text { biochemical data }\end{array}$ & \\
\hline Total & 120 & 188 & 78 & 96 & & & \\
\hline \multicolumn{8}{|l|}{ Reticulin staining } \\
\hline Volante et al. (2009) & 92 & 47 & 100 & 100 & RA & WS & \\
\hline Duregon et al. (2011) & 6 & 1 & 83 & 100 & RA & $\begin{array}{l}\text { Lin-Weiss-Bisceglia } \\
\text { system }\end{array}$ & $\begin{array}{l}\text { Only OACTs } \\
\text { included }\end{array}$ \\
\hline Duregon et al. (2013a) & 184 & 61 & 97 & 100 & RA & WS & \\
\hline Total & 282 & 109 & 98 & 100 & & & \\
\hline
\end{tabular}

Sens, sensitivity; spec, specitificy; NR, not reported; LOH, loss of heterozygosity; IHC, immunohistochemistry; LI, labeling index, defined as the number of Ki67/MIB1-positive cells per 100 tumor cells; TPF, tumor proliferating fraction, expressed as the number of Ki67/MIB1-positive nuclei per 1000 tumor cells; RA, reticulin algorithm, defined as the presence of disruption of reticular networks with at least one of the following parameters - necrosis, high mitotic rate or vascular invasion; OACT, oncocytic adrenocortical tumors.

applicable (Table 2; Papotti et al. 2010, Duregon et al. 2011, de Krijger \& Papathomas 2012).

\section{Future directions in diagnosing ACC}

Because both imaging and histopathological criteria cannot completely predict biological behavior of adrenal tumors, research now focuses on new imaging techniques and genomic or molecular markers for discrimination between ACCs and ACAs.

Imaging Several studies have focused on the diagnostic value of positron emission tomography (PET) using ${ }^{11} \mathrm{C}$-labeled metomidate (MTO) for lesions in the adrenal cortex. Metomidate binds with high specificity and affinity to CYP11B enzymes, which are expressed in the adrenal cortex. Two studies compared MTO-PET with FDG PET in adrenocortical tumors (Minn et al. 2004, Zettinig et al. 2004). In a total of 37 patients, MTO-PET appeared to only differentiate lesions of adrenal from those of nonadrenal origin, while FDG PET was able to identify malignancy of the adrenal tumor. Another study that investigated the correlation between MTO-PET scan results, histopathology, and hormonal secretion of the adrenals, found that MTO-PET could diagnose adrenocortical origin of the lesion with a sensitivity of $89 \%$ and specificity of $96 \%(n=75)$ (Hennings et al. 2006).

$\left[{ }^{123} \mathrm{I}\right]$ iodometomidate ([$\left.\left.{ }^{123} \mathrm{I}\right] \mathrm{IMTO}\right)$ for single-photon emission computed tomography imaging is recently developed and shows high and specific uptake of

Published by Bioscientifica Ltd 

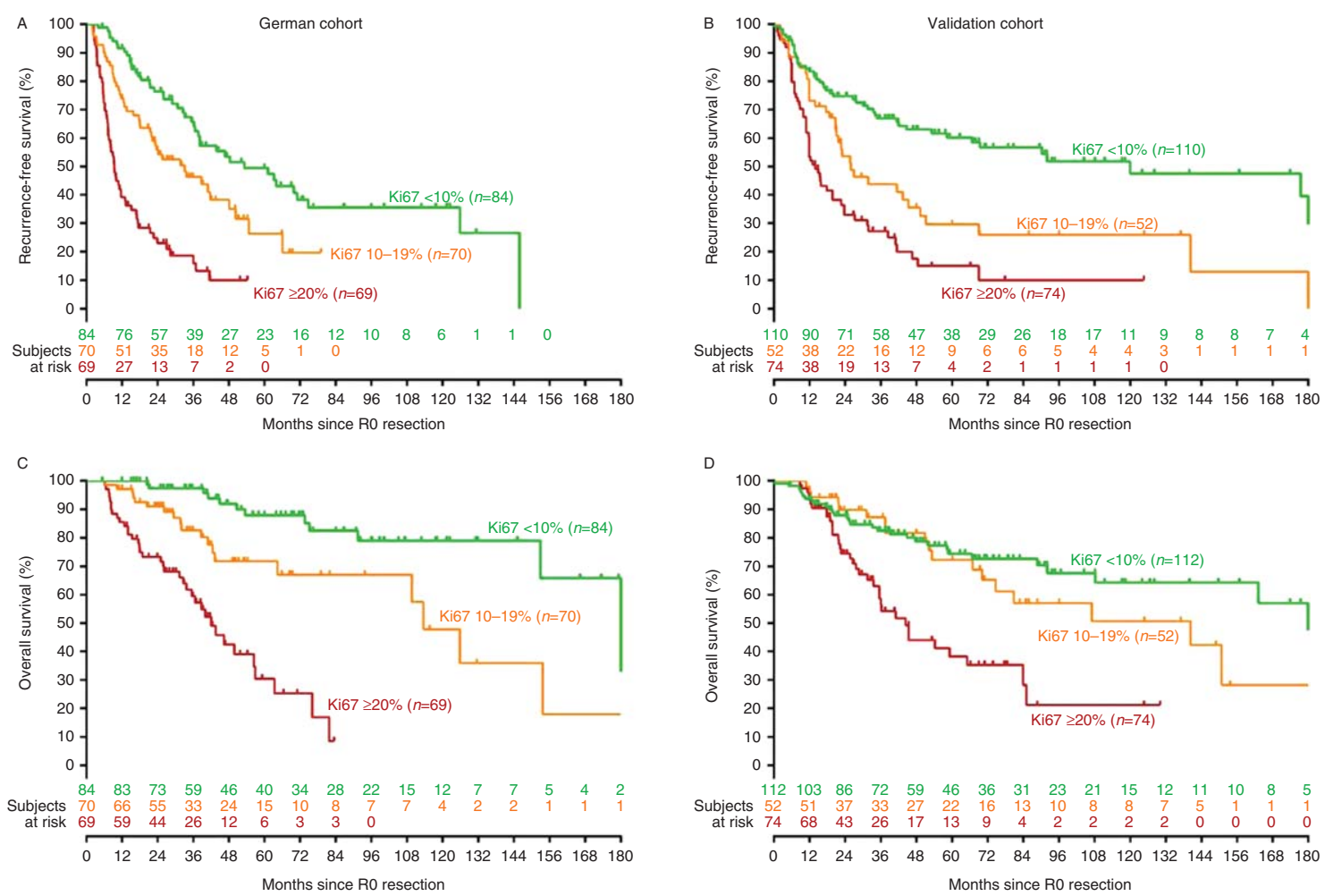

\section{Figure 1}

Kaplan-Meier analysis of Ki67 index on recurrence-free survival (A and B), and overall survival ( $C$ and $D$ ) of the German cohort ( $A$ and $C$ ) and the validation cohort ( $B$ and $D$ ) respectively. Republished with permission of The Endocrine Society, from Journal of Clinical Endocrinology and Metabolism; Major prognostic role of Ki67 in localized adrenocortical

$\left[{ }^{123} \mathrm{I}\right] \mathrm{IMTO}$ in adrenocortical tissue (Hahner et al. 2008). IMTO binds to both $11 \beta$-hydroxylase and aldosterone synthase and is able to identify the adrenocortical origin of the lesion, but not malignancy of the lesion. IMTO does show uptake in metastasis of ACC (Hahner et al. 2013, Kreissl et al. 2013). In two studies, sensitivity and specificity for characterization of adrenal lesions was $89 \%$ and $85 \%$, and $38 \%$ and $100 \%$ respectively (Hahner et al. 2013, Kreissl et al. 2013).

Early results suggest that proton MR spectroscopy may be useful in discriminating pheochromocytomas and adrenal adenomas from adrenal metastases and ACC. Faria et al. (2007) found that a choline:creatine ratio greater than 1.20 yielded a sensitivity of $92 \%$ and a specificity of $96 \%$. Furthermore, choline:lipid ratios greater than 0.38 could differentiate adenomas and pheochromocytomas from carcinomas and metastases with a sensitivity of $92 \%$ and a specificity of $90 \%$ (Faria et al. 2007). Further studies are needed to validate this approach.

carcinoma after complete resection; Beuschlein F, Weigel J, Saeger W Kroiss M, Wild V, Daffara F, Libe R, Ardito A, Al Ghuzlan A, Quinkler M, et al.; volume 100; pages 841-849; copyright 2015; permission conveyed through Copyright Clearence Center, Inc.

\section{Molecular markers}

Differential gene expression Several studies have shown that ACCs and ACAs have different gene expression profiles, which can be used to discriminate the two entities. IGF2 is the most widely known overexpressed gene in ACCs. Besides the microarray studies, several studies have shown overexpression of IGF2 with qPCR and immunohistochemistry. However, IGF2 alone appears not to be sufficient to accurately discriminate ACCs from ACAs (Table 2). By comparing microarray data of 33 ACAs and 24 ACCs, de Fraipont et al. (2005) identified two clusters of genes whose combined levels of expression could correctly discriminate ACCs from ACAs. Overall, 75\% of ACCs expressed high levels of the IGF2 cluster, containing eight genes, whereas $93 \%$ of ACAs highly expressed fourteen genes representing the steroidogenesis cluster. After this finding, several other studies also reported differential expression levels in ACCs compared to ACAs, as well as a more heterogeneous transcriptional profile in ACCs versus ACAs (Giordano et al. 2003, 2009, Velazquez-Fernandez

Published by Bioscientifica Ltd 
et al. 2005, Slater et al. 2006). Soon et al. (2009a) more specifically selected two factors, IGF2 and Ki-67, which in combination resulted in a high diagnostic accuracy for ACCs (96\% sensitivity, 100\% specificity). Several other factors were also differentially expressed in ACCs compared to ACAs, like MAD2L1, CCNB1, ABLIM1, NAV3, SEPT4, and RPRM (Soon et al. 2009a). Another microarray study showed 614 significant differentially expressed genes (Tombol et al. 2009), of which several were previously described to be similarly differentially expressed between ACCs and ACAs (Giordano et al. 2009, Soon et al. 2009a). The most differentially expressed genes in this series were TOP2A and IGF2, CCNB2, CDC2, CDC25C and CDKN1C (Tombol et al. 2009). In another series by Laurell et al. (2009) comparing 11 ACCs and 17 ACAs, ALDH1A1, IGF2, USP4 and UFD1L were the four most differentially expressed genes. The gene expression profiles were subjected to hierarchical clustering, resulting in two subclusters of patients with short survival $(<9$ months) and long survival (>67 months), suggesting that gene expression profiles can be used to predict survival (Laurell et al. 2009). Another gene of interest in adrenal tumors, the steroidogenic factor 1 ( $S F 1)$ gene, has been shown to have a role in adrenocortical cell proliferation (Doghman et al. 2007). It also appeared to identify the adrenocortical derivation of the tumor with high diagnostic accuracy and also has a high prognostic value (Sbiera et al. 2010, Sangoi et al. 2011, Duregon et al. 2013b). Besides the fact that overexpression of SF1 is associated with a poor prognosis, its oncogenic effect is also emphasized by its chromosomal location (9q34), which is frequently gained in ACC (see the 'Chromosomal aberrations' section).

These findings together highlight that expression profiles provide more insights into the pathogenesis of ACCs and the main pathways involved (Fig. 2). However, the interpretation of these findings is still difficult, since there are considerable differences between the different studies. Whether this is due to the heterogeneity of the series of patients studied, the different analyses methods or both, remains unclear.

Methylation The rationale that aberrant methylation patterns in tumor cells can cause altered gene expression

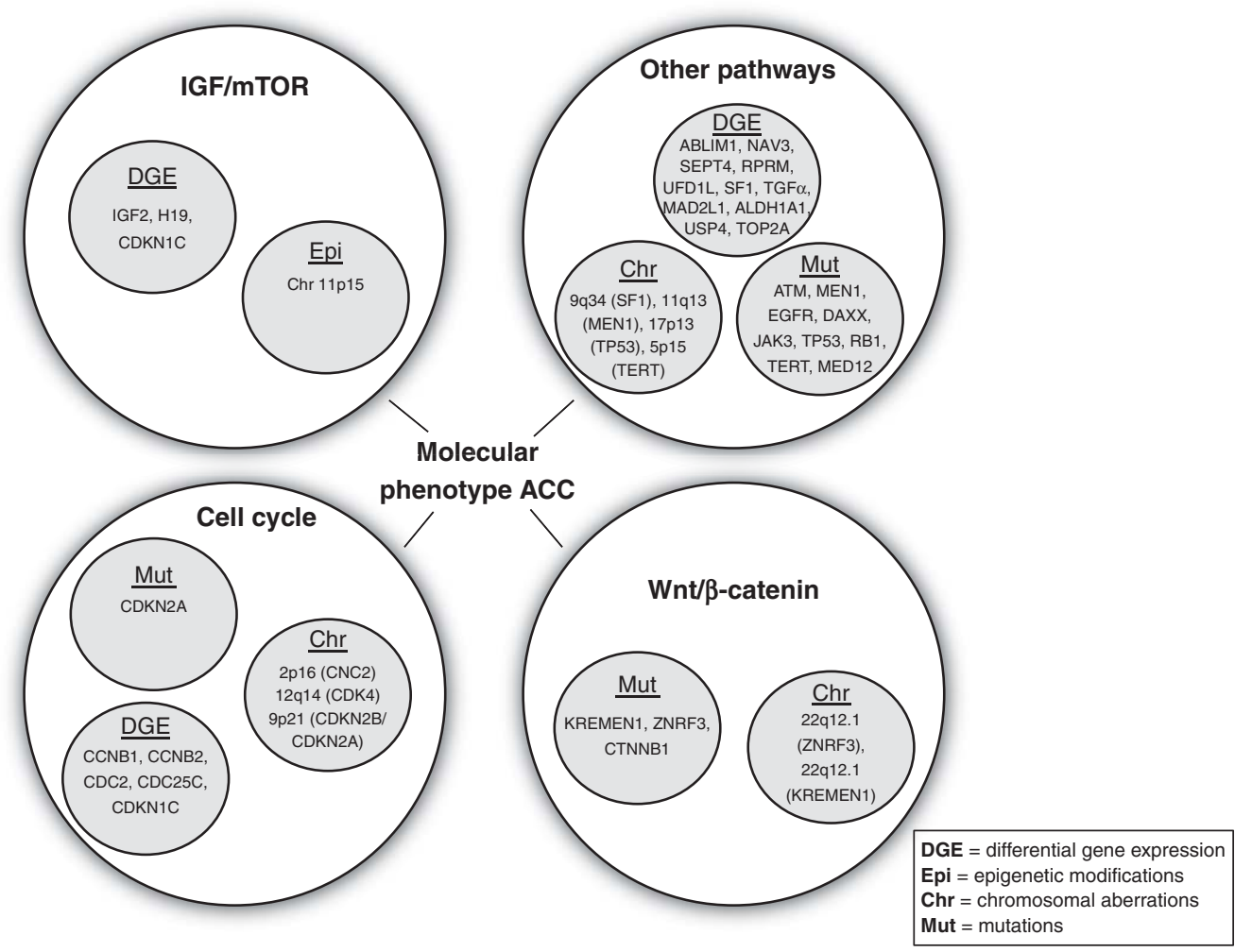

Figure 2

Most frequently altered pathways in adrenocortical carcinomas (ACC) compared to adrenocortical adenomas (ACA), with molecular aberrations involving the cell cycle-, the IGF/mTOR-, and the Wnt/ $\beta$-catenin pathway.
Alterations are organized per molecular aberration. DGE, differential gene expression, consisting of both up- and downregulated genes in ACC; Epi, epigenetic modifications; Chr, chromosomal aberrations; Mut, mutations. 
resulting in tumorigenesis is now another focus in ACC research (Das \& Singal 2004). To date, research has focused on candidate gene approaches as well as genome-wide methylation level analysis. Insights and interest in the imprinted IGF2 gene comes from an association of ACC with the BWS (Wiedemann 1983). In these patients, genes regulated by the $11 \mathrm{p} 15$ chromosomal region - IGF2, H19, and CDKN1C - show altered expression (Demars et al. 2011). In sporadic ACC, DNA methylation of the H19 promoter has been shown to be correlated with $\mathrm{H} 19$ and IGF2 expression (Fig. 2; Gao et al. 2002). TP53 methylation, in contrast to some other types of cancer, is not present in ACC as a mechanism of tumor suppressor gene inactivation (Sidhu et al. 2005). A genome-wide approach to study methylation status was first performed by Rechache et al. (2012). Global hypomethylation was found in primary $(n=8)$ and metastatic $(n=12)$ ACC samples compared to normal adrenals $(n=19)$ and ACAs $(n=48)$. Fifty-two genes were down-regulated and hypermethylated in primary adrenocortical tumor samples, suggesting methylation as a potential regulator of expression in ACC (Rechache et al. 2012). Fonseca et al. (2012) analyzed 27578 CpG sites in 6 normal adrenals, 27 ACAs and 15 ACCs. Two hundred and twelve CpG islands in promoter regions of genes involved in cell cycle regulation, apoptosis, and transcriptional regulation, were significantly hypermethylated in ACCs compared to ACAs and normal adrenal tissues. Of six selected genes, mRNA expression levels were concordantly significantly reduced in ACCs compared to ACAs and normal adrenal tissue (Fonseca et al. 2012). Along with this finding, Barreau et al. (2013) also confirmed ACC-specific hypermethylation in promoter regions in a series of 51 ACCs and 84 ACAs. In addition, Barreau et al. (2013) also correlated the methylation levels with prognostic features in patients with ACC (see the 'Prognostic and predictive markers' section).

In conclusion, DNA methylation patterns appear to identify subgroups of adrenal tumors with benign or malignant behavior. The main challenge is to use these global methylation studies not only for a better understanding of ACC pathogenesis, but also to identify specific abnormalities that can be informative for the individual patient.

miRNAs Several studies have focused on the relevance of microRNAs (miRNAs), short noncoding sequences regulating gene expression post-transcriptionally (Malumbres 2013), in the pathogenesis and diagnosis of adrenocortical tumors. MiR-483-5p and miR-483-3p are the most consequently overexpressed miRNAs in ACCs compared to ACAs, whereas miR-195 is often found to be underexpressed (Soon et al. 2009b, Patterson et al. 2011, Ozata et al. 2011, Chabre et al. 2013). The hypothesized mechanism of pathogenesis of these specific miRNAs in ACC are mainly based on in vitro results and studies in other types of tumors (Igaz et al. 2015). Overexpression of miR-483-5p, miR-503, miR-1202, and miR-1275, and underexpression of miR-195 were associated with poor survival in ACC (Soon et al. 2009b, Ozata et al. 2011). Different combinations of several miRNAs (miR-483-5p, miR-195, miR-503, miR-511, miR-335, miR-675, miR-139-3p) could identify malignancy of adrenal tumors (Soon et al. 2009b, Tombol et al. 2009, Patterson et al. 2011, Schmitz et al. 2011). Other studies, such as Caramuta et al. (2013), have shown overexpression of miRNA-processing enzymes, i.e. DICER, TARBP2 and DROSHA, at protein level, of which TARBP2 also strongly discriminated carcinomas from adenomas (Caramuta et al. 2013). To date, three studies expanded on using serum miRNAs, of which miR-483 harbors the highest potential for use as a noninvasive biomarker (Chabre et al. 2013, Patel et al. 2013, Szabo et al. 2014). Although it would be very valuable to attain a noninvasive biomarker for the follow-up of patients with ACC, these findings still have to be validated.

\section{Genetics}

Chromosomal aberrations Comparative genomic hybridizion (CGH) studies can identify structural chromosomal alterations within ACCs. Studies have shown that ACCs harbor mainly monoclonal cells, whereas benign tumors can be monoclonal as well as polyclonal (Beuschlein et al. 1994, Gicquel et al. 1994). This suggests the presence of a genetic alteration resulting in a growth advantage in ACCs. Studies of adrenocortical tumors have shown a complex pattern of chromosomal alterations in ACCs, while ACAs present few regions of chromosomal gains and losses (Kjellman et al. 1996, Zhao et al. 1999, Dohna et al . 2000, Sidhu et al. 2002, Gruschwitz et al. 2010, Barreau et al. 2012). It is thought that oncogenes and tumor suppressor genes are located in regions of gains and losses respectively. CGH studies have identified frequent allelic losses in ACCs in the TP53 region 17p13 (85\%), the MEN1 locus 11q13 (92\%), and the Carney Complex region 2p16 (90\%) (Kjellman et al. 1996, Gicquel et al. 2001). Some studies support the concept of a progression model, whereas genetic aberrations were correlated with tumor size (Kjellman et al. 1996, Zhao et al. 1999, 2002,

Published by Bioscientifica Ltd. 
Sidhu et al. 2002). Sidhu et al. (2002) showed that ACCs $(n=13)$ harbored the most frequent gains on chromosome 5, 12, 19 and 4. Losses were most commonly seen on chromosome 1p, 17p, 22, 2q and 11q. A cut-off of 4 or more $\mathrm{CGH}$ alterations in one tumor was strongly suggestive for malignancy of the adrenocortical tumor (Sidhu et al. 2002). Stephan et al. (2008) reported that some of the alterations found (amplifications in $6 \mathrm{q}, 7 \mathrm{q}$ and $12 \mathrm{q}$, and losses in chromosomes 3, 8, 10p, 16q, and 19q) were associated with decreased overall survival. Barreau et al. (2012) found frequent gains of the 9q34 region in adenomas, which includes the steroidogenic factor 1 (SF1) gene. Gain of region 9q34 is also frequently found in pediatric ACC (Figueiredo et al. 1999, James et al. 1999, Pianovski et al. 2006), in which it has also been suggested to be involved in tumorigenesis based on mRNA overexpression and strong SF1 staining (Figueiredo et al. 2000, Almeida et al. 2010). Barreau et al. (2012), who used a higher-resolution CGH array, also developed a diagnostic tool to identify malignancy of adrenal tumors with a sensitivity of $100 \%$ and a specificity of $83 \%$ by combining DNA copy number estimates at six loci $(5 q, 7 p, 11 p, 13 q$, $16 \mathrm{q}$, and 22q). This tool was validated in an independent cohort of 79 tumors. Cluster analysis based on gains and losses in DNA could also identify two groups of ACC with different survival rates (Barreau et al. 2012). Partly in concordance, in a study by Ronchi et al. (2013) chromosomes $1,5,7$, and 12 were selected to separate ACCs $(n=22)$ from ACAs $(n=24)$, which appeared more evident when considering only chromosome 5. More recently, frequent recurrent copy number variations were identified at 5p15 and deletions at 22q12.1 (Juhlin et al. 2015). Regions contain TERT, encoding telomerase reverse transcriptase, and the ZNRF3 gene, which is recently reported to act as a tumor suppressor gene respectively (Hao et al. 2012).

These studies together show the diversity and heterogeneity of chromosomal gains and losses in ACC (Fig. 2). It is thus not surprising that so far no specific pattern among different tumors has been characterized. The utility of chromosomal aberrations in diagnosing malignancy of adrenocortical tumors remains to be elucidated and needs to be further investigated in larger more specific studies focusing on the most promising regions.

Mutations The association of TP53 gene mutations with ACC has been discovered in patients with the Li-Fraumeni syndrome (Birch et al. 2001), who appeared to have TP53 germline mutations and presented with ACCs (Malkin et al. 1990). Another line of indirect evidence of TP53 involvement in adrenocortical tumorigenesis is the frequent loss of chromosomal locus $17 \mathrm{p}$ (see the 'Chromosomal aberrations' section) (Libe et al. 2007). TP53 mutations occur in 25 to $35 \%$ of sporadic ACC in adults and are thought to be associated with a shorter disease-free survival (Reincke et al. 1994, Libe et al. 2007, Wasserman et al. 2012). Furthermore, the prevalence of TP53 mutations is higher in pediatric ACC (Wagner et al. 1994, Varley et al. 1999). Other studies have confirmed the relatively high frequencies of TP53 mutations in ACC, ranging from 15 to 19.5\% (De Martino et al. 2013, Assie et al. 2014, Juhlin et al. 2015).

The second most frequently mutated driver gene in ACC is CTNNB1 ( $\beta$-catenin). Mutations in CTNNB1 lead to activation of the WNT signaling pathway and these mutations have been shown to be a common event in both ACCs and ACAs (varying from 20 to $30 \%$ of samples; Tissier et al. 2005, Gaujoux et al. 2008, Masi et al. 2009). Upregulation of $\beta$-catenin in adrenocortical tumors was also confirmed with immunohistochemistry (Tissier et al. 2005). More recently, the high frequency of CTNNB1 mutations in ACC was confirmed by several studies, which reported somatic mutation frequencies of 10-16\% (De Martino et al. 2013, Assie et al. 2014, Juhlin et al. 2015). Notably, TP53 and CTNNB1 mutations are mutually exclusive.

Recently, Assie et al. (2014) identified ZNRF3 as a new tumor suppressor gene driving ACC pathogenesis, with inactivation of ZNRF in $21 \%$ of ACCs. Inactivation was caused by a homozygous deletion in $75 \%$ of the mutated cases, whereas the other $25 \%$ were caused by missense and nonsense mutations. The frequency of ZNRF3 mutations was even higher than TP53 mutations (16\%) in this study (Assie et al. 2014). In addition, mutations in ZNRF3 and CTNNB1 appeared to be mutually exclusive. A second recent study confirmed this mutually exclusive behavior, although the frequency of ZNRF3 mutations was lower (10\%) compared to the former study (Juhlin et al. 2015).

Other genes that are relatively frequently mutated in ACC, include $A T M(\sim 13 \%), C D K N 2 A(\sim 11 \%), R B 1(\sim 4$ to 7\%), MEN1 ( 7\%), KREMEN1 ( 7\%), DAXX ( 6\%), TERT ( 6\%), MED12 $(\sim 5 \%)$ and JAK3 $(\sim 4 \%)$, which almost always co-occurs with mutations in TP53, CTNNB1, or ZNRF3 (De Martino et al. 2013, Assie et al. 2014, Ragazzon et al. 2014, Juhlin et al. 2015). Three additional studies screened for EGFR mutations in ACC and reported different frequencies, i.e. 0, 11 and 0\% (Ameur et al. 2009, Kotoula et al. 2009, Adam et al. 2010).

Four studies have screened ACCs simultaneously for mutations and copy number alterations using (targeted)

Published by Bioscientifica Ltd. 
next generation sequencing and CGH. In the first study, in which a large number of structural DNA changes in ACC was analyzed, TP53 was found to be mutated in 15\% of cases, ATM in $12.5 \%$ of cases and CTNNB1 in $10 \%$ (De Martino et al. 2013). Most frequent copy number alterations were amplification of the CDK4 gene, and deletion of the $C D K N 2 A$ and $C D K N 2 B$ genes. Interestingly, these genes are known actors of the RB/E2F pathway. Overall, 19/40 ACCs (47.5\%) had at least one molecular abnormality (De Martino et al. 2013). In a second study, Ross et al. (2014) recently performed a comprehensive genomic profiling of 29 ACC samples and found at least one alteration (a mutation, amplification, deletion, or truncation) in 22 cases (76\%). Genomic alterations in NF1 (14\%), CDKN2A (14\%), ATM (10\%), CCND2 (7\%), CDK4 (7\%) and DNMT3A (7\%) were considered as the most common and potentially clinically relevant at the same time (Ross et al. 2014). The third study showed, considering the different omics classifications, a strong correlation between clustering of patients with different prognosis based on transcriptome clusters, DNA methylation and miRNA expression (Assie et al. 2014). The fourth study investigated recurrent copy number variations using the coverage of paired exome sequencing results (patient's tumor vs normal), and reported somatic amplification of the TERT gene and deletion of ZNRF3 and KREMEN1 genes (Juhlin et al. 2015).

Based on the two most recent studies that used different genomic approaches, we can conclude that the Wnt signaling pathway is most frequently altered in ACCs (Assie et al. 2014, Juhlin et al. 2015). Figure 2 gives an overview of the most frequently altered pathways in ACCs compared to ACAs. However, because of the lack of a discriminative value and the relative rarity of genetic abnormalities in ACCs, mutation studies are not primarily used to diagnose ACCs, but specifically to identify potential novel targets for therapy (see the 'Future directions and pathway driven therapies' section).

Urine metabolomics Urine metabolomics might offer an alternative diagnostic tool for malignancy of adrenal tumors and is based on excessive amounts of adrenal steroids secreted by ACCs. It has been shown to be relevant as a diagnostic tool and as a tumor marker during follow-up (Grondal et al. 1990). More recently, in a series of 102 patients with ACAs and 45 with ACCs, urinary steroid profiling differentiated ACCs from ACAs with a sensitivity and specificity of 90\% (Arlt et al. 2011). Kerkhofs et al. (2015) showed that tetrahydro-11-deoxycortisol (THS) at a cut-off value of
$2.35 \mu \mathrm{mol} / 24 \mathrm{~h}$ differentiated ACC $(n=27)$ from other adrenal disorders $(n=125)$ with a sensitivity of $100 \%$ and specificity of $99 \%$.

\section{Treatment of ACC}

\section{Current therapeutic strategies}

Surgery Complete R0 resection of ACC is currently the keystone and only curative treatment modality for patients with ACC. However, even after complete resection the recurrence rates are high (30-50\%; Fassnacht et al. 2010, 2011, Lafemina \& Brennan 2012) and often occur with metastases (Bellantone et al. 1997, Schulick \& Brennan 1999, Icard et al. 2001, Terzolo \& Berruti 2008). Resection status is one of the most important prognostic factors. To reduce the amount of recurrences, it is recommended to perform adrenalectomies only in specialized centers performing at least 20 adrenalectomies per year (Kerkhofs et al. 2013a, Ronchi et al. 2014a). A recent systematic review reported that open adrenalectomy with lymph node dissection should be regarded as standard treatment for ACC (Bellantone et al. 2015). However, for patients with stage I-II ACCs with a diameter $<8$ to $10 \mathrm{~cm}$, laparoscopic resection may be performed if oncological standards are respected. In addition, for patients in ENSAT stage IV or patients with hormone excess, debulking surgery can be helpful. Though, clinical effects and effects on response to systemic therapy after surgery are still unclear (Ronchi et al. 2014a). However, Livhits et al. (2014) showed that even in patients with metastatic disease, surgery was associated with improved survival.

Adjuvant treatment Mitotane, a synthetic derivative of the insecticide dichlorodiphenyltrichloroethane, is an adrenolytic drug. Mitotane is thought to act primarily by disruption of mitochondria and thereby activate an apoptotic process (Poli et al. 2013). Sbiera et al. (2015) recently identified endoplasmic reticulum stress as a key molecular pathway activated by mitotane. Sterol-O-AcylTransferase 1 (SOAT1) was identified as a key molecular target, which expression was also correlated with response to mitotane. This adrenal specific drug is difficult to manage clinically and mitotane use is often accompanied by severe adverse effects, sometimes leading to drug withdrawal (Allolio \& Fassnacht 2006). Side effects mainly consist of gastrointestinal (nausea and diarrhea), neurological (confusion and sleepiness), metabolic, and endocrine effects. The target plasma concentration of mitotane is 14 to $20 \mathrm{mg} / \mathrm{l}$ and monitoring is of great importance.

Published by Bioscientifica Ltd 


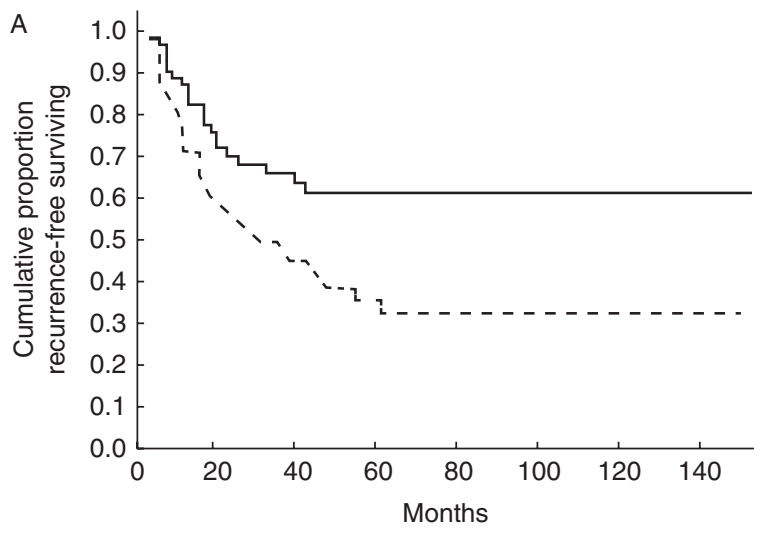

\begin{tabular}{|c|c|c|c|c|c|c|c|c|}
\hline $\begin{array}{c}\text { No. of } \\
\text { patients at risk }\end{array}$ & 0 & 20 & 40 & 60 & 80 & 100 & 120 & 140 \\
\hline Group 1 & 63 & 33 & 21 & 14 & 10 & 8 & 7 & 3 \\
\hline Group 2 & 59 & 27 & 12 & 6 & 1 & 1 & - & - \\
\hline
\end{tabular}

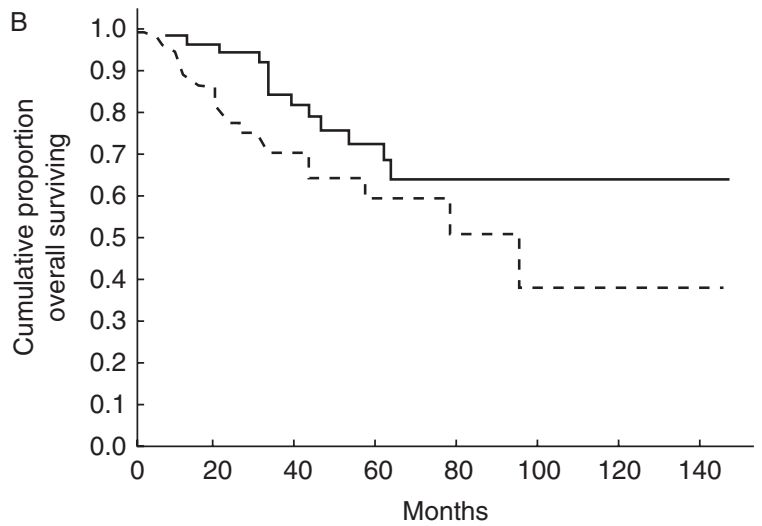

\begin{tabular}{|c|c|c|c|c|c|c|c|c|}
\hline $\begin{array}{c}\text { No. of } \\
\text { patients at risk }\end{array}$ & 0 & 20 & 40 & 60 & 80 & 100 & 120 & 140 \\
\hline Group 1 & 63 & 45 & 26 & 13 & 9 & 7 & 3 & 1 \\
\hline Group 2 & 59 & 41 & 24 & 8 & 6 & 2 & 2 & 1 \\
\hline
\end{tabular}

\section{Figure 3}

(A) Kaplan-Meier estimates for recurrence-free survival during adjuvant mitotane therapy. Solid line, patients with mitotane levels higher than 14 $\mathrm{mg} / \mathrm{l}$ during follow-up $(n=63)$; dashed line, patients with mitotane levels lower than $14 \mathrm{mg} / \mathrm{l}$ during follow-up $(n=49)$. (B) Kaplan-Meier estimates for overall survival during adjuvant mitotane therapy. Solid line, patients who reached and maintained mitotane levels of $14 \mathrm{mg} / \mathrm{l}$ or greater during followup $(n=63)$; dashed line, patients with mitotane levels lower than $14 \mathrm{mg} / \mathrm{l}$ during follow-up $(n=49)$. Reproduced, with permission, from Terzolo M, Baudin AE, Ardito A, Kroiss M, Leboulleux S, Daffara F, Perotti P, Feelders RA, deVries JH, Zaggia B, et al. (2013) Mitotane levels predict the outcome of patients with adrenocortical carcinoma treated adjuvantly following radical resection. European Journal of Endocrinology 169 263-270.

Several studies have shown that patients with advanced ACC who reached this target concentration had less recurrences and showed a prolonged recurrence-free survival (Fig. 3; Terzolo \& Berruti 2008, Hermsen et al. 2011,
Terzolo et al. 2013). Kerkhofs et al. (2013c), who investigated the optimal dosing strategy, showed that $50 \%(10 / 20)$ of patients from the high dose starting regimen and 33\% (4/12) of patients from the low-dose regimen reached the therapeutic level within 3 months. No significant differences were observed in frequency and severity of adverse events. Mitotane is known to induce CYP3A4 activity, which indicates relevant drug interactions with mitotane (Kroiss et al. 2011). This issue needs to be considered when designing clinical trials in patients with ACC (Kroiss et al. 2011). This CYP3A4 induction can also, together with suppression of $11 \beta$ hydroxylase and cholesterol side chain cleavage, lead to hypocortisolism (Touitou et al. 1978, Ghataore et al. 2012). The adrenolytic effect of mitotane on the healthy contralateral adrenal, as well as enhanced production of cortisol-binding globuline in mitotane treated patients, also play a role in the occurrence of hypocortisolism (Nader et al. 2006), which should be prevented by supraphysiological hydrocortisone replacement therapy.

In case of radically resected ACC, the first line adjuvant treatment recommendation is mitotane (Terzolo \& Berruti 2008, Terzolo et al. 2012, Fassnacht et al. 2013). Adjuvant treatment is mandatory in patients with high recurrence risk, because the postoperative 5 years diseasefree survival is only around 30\% (Allolio \& Fassnacht 2006). However, studies investigating efficacy of mitotane as adjuvant treatment all have a retrospective design (Table 3). Therefore, this issue is currently addressed in a multicenter phase III trial recruiting patients with low to intermediate risk of recurrence (ADIUVO). In case of locally advanced or metastatic disease, approximately $25-30 \%$ of patients with ACC respond (defined according to different response evaluation criteria) to mitotane treatment (Table 4). Combination of mitotane with chemotherapy for advanced ACC is investigated in the first randomized trial in ACC, showing that patients receiving mitotane with etoposide, doxorubicine and cisplatin (EDP) had a longer median progression-free survival compared to patients receiving streptozotocin and mitotane (5.0 vs 2.1 months) (Fassnacht et al. 2012). Based on this trial, mitotane with EDP is preferred above mitotane with etoposide. However, the median overall survival in the mitotane with EDP group was still only 14.8 months, underscoring the limitation of cytotoxic drugs.

Postoperative radiotherapy Previously, ACC was considered a radiotherapy resistant disease and studies reported poor and contradictive results of radiotherapy after surgery (Polat et al. 2009, Else et al. 2014).

Published by Bioscientifica Ltd 

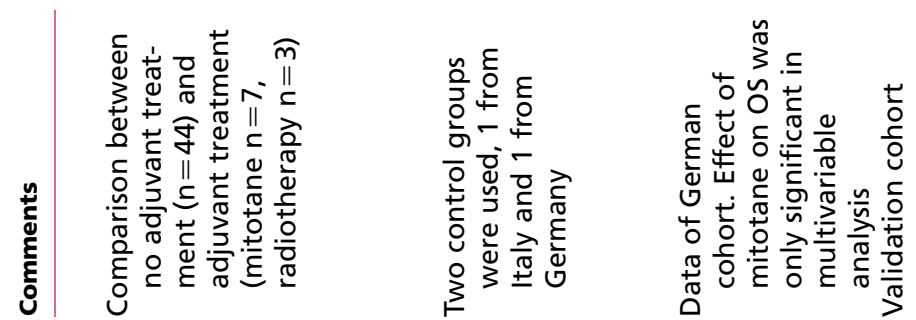

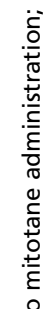

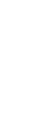
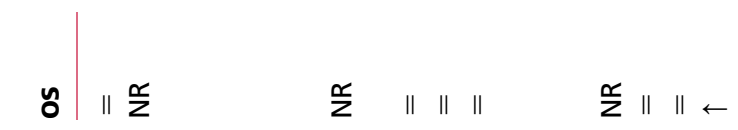

๕ุ
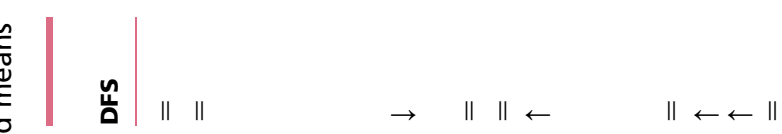

혼
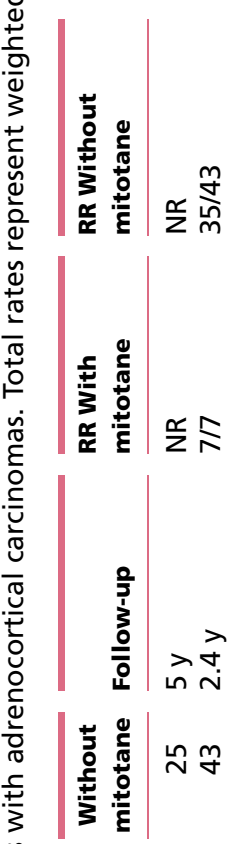

$\frac{\infty}{z} \frac{\infty}{z} \frac{}{\infty} \stackrel{\frac{0}{m}}{=}$
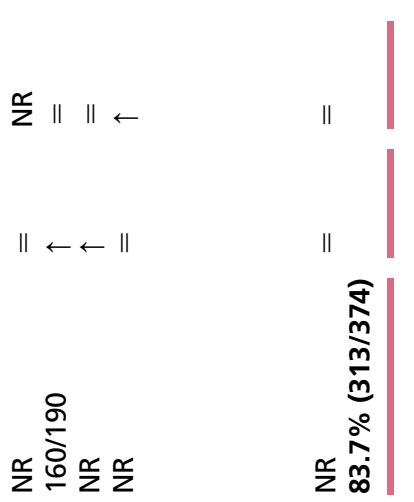

\begin{tabular}{l}
2 \\
0 \\
0 \\
0 \\
0 \\
0 \\
0 \\
0 \\
\hline
\end{tabular}

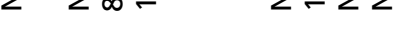

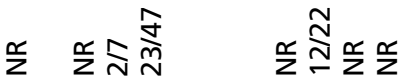

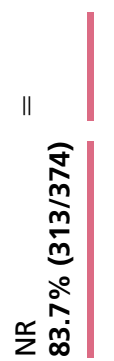

$\bar{\varepsilon}$
$\bar{d}$
$\sum_{d}$

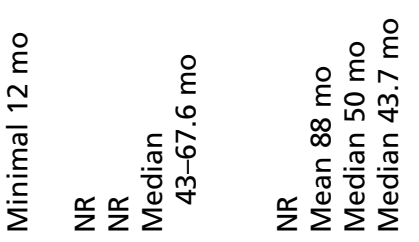

-
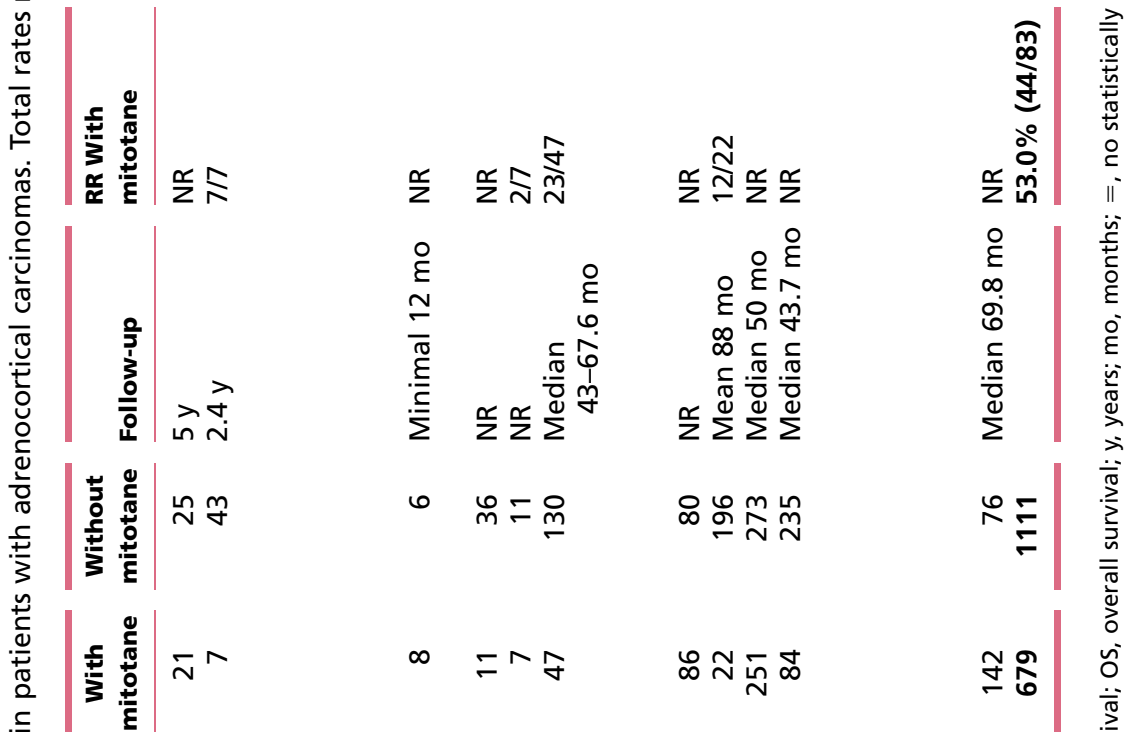

$\infty$ テテ $\quad \infty \underset{\sim}{\sim}$

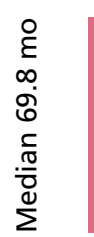

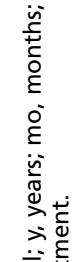
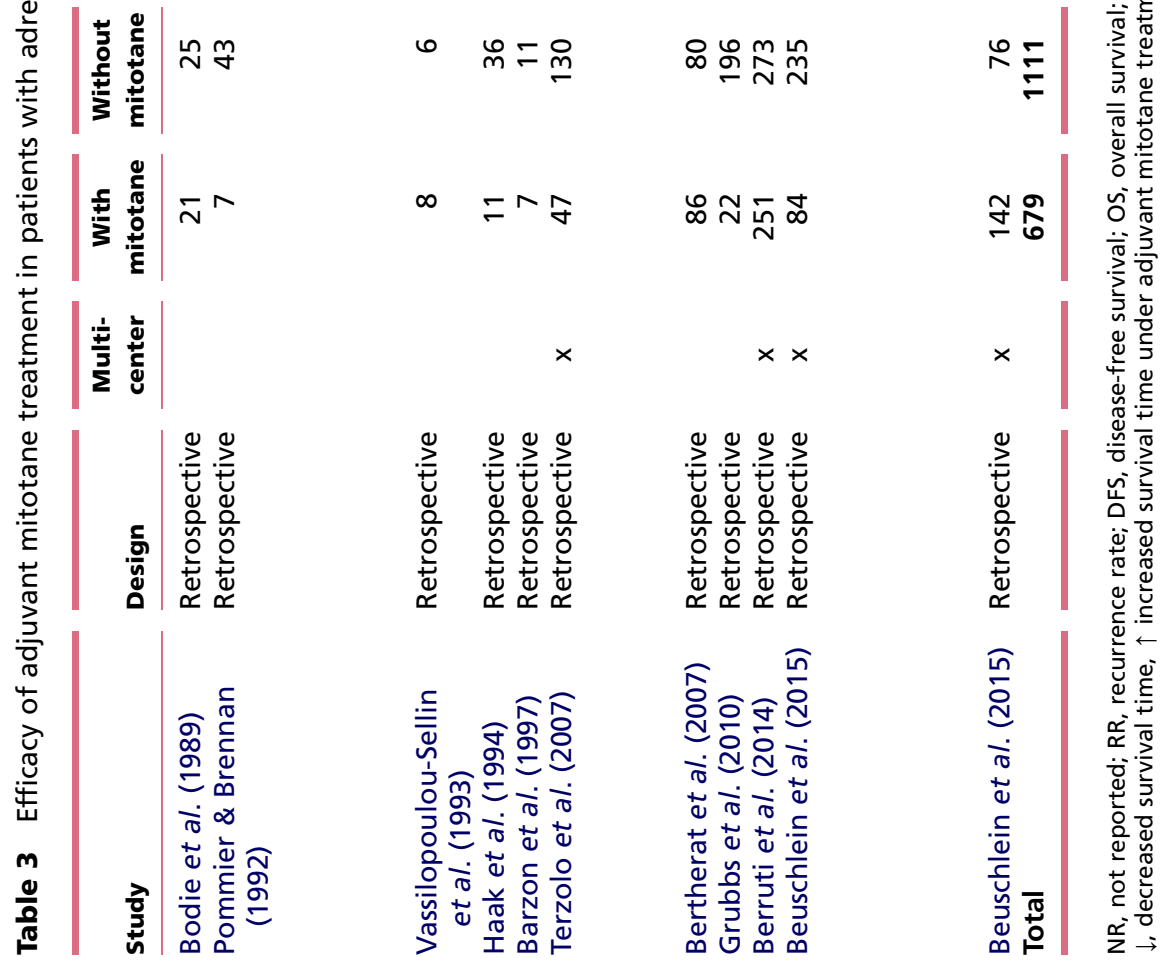

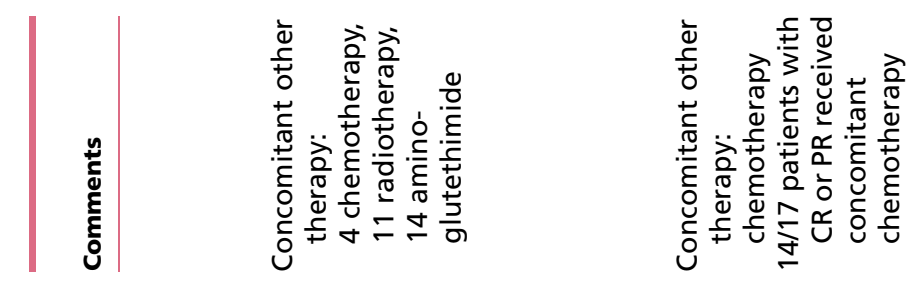

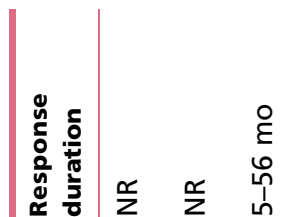

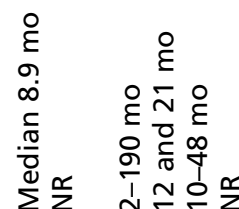

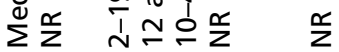

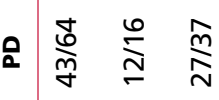

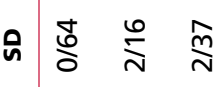

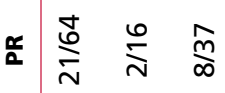

$\approx$ ษ

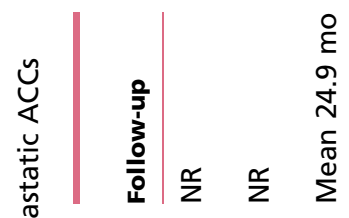

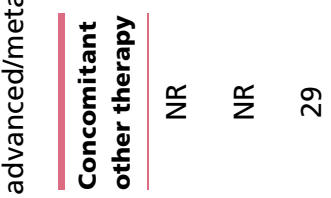

ᄒे

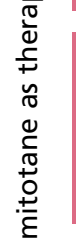

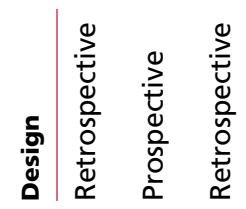

窇

竞

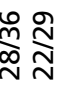

ํํำ

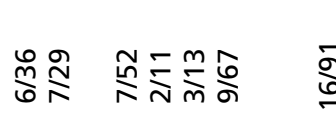

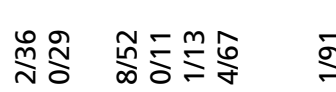

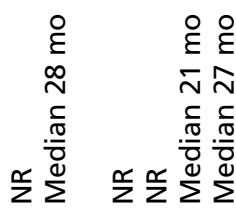

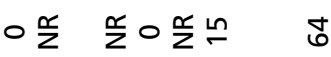

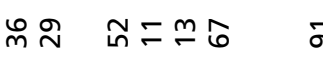

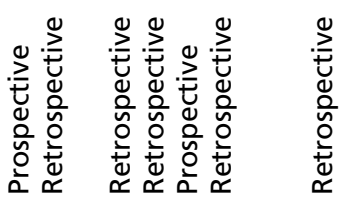

ลัฐ

氟

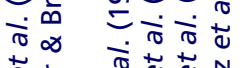

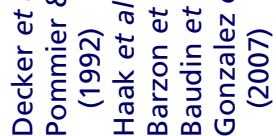

হু

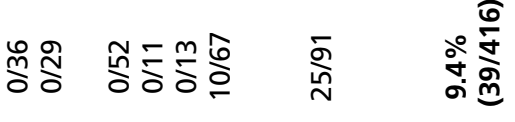

হ

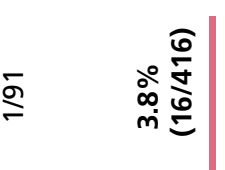

离

这 
More recently, several studies with a total of 45 patients treated in an adjuvant setting show local control in 56 to $100 \%$ of patients (Fassnacht et al. 2006, Hermsen et al. 2010, Sabolch et al. 2011, Habra et al. 2013, Ho et al. 2013). However, no increase of disease-free or overall survival was found. The ultimate protocol should be adapted according to patient and tumor characteristics. In vitro results suggest that the combination of irradiation with simultaneous mitotane synergistically inhibits ACC cell growth (Cerquetti et al. 2008).

Apart from the adjuvant setting, radiotherapy can be indicated: i) when microscopic tumor residues are visible after surgery; ii) when patients are not suitable for surgery (in this case radiotherapy is often in combination with mitotane); and iii) for palliative care. Several studies have shown efficacy of radiotherapy for adequate palliation, but with divergent results and mainly based on case series (Else et al. 2014). The three most recent studies reported 8, 12 and 22 patients treated in palliative setting, respectively, with response rates varying from $77 \%$ to $100 \%$ (Polat et al. 2009, Hermsen et al. 2010, Ho et al. 2013).

Treatment of hormone excess In $40-60 \%$ of patients with ACC, the main complaints are due to hormone overproduction (Allolio \& Fassnacht 2006, Fassnacht \& Allolio 2009). Treatment of these elevated hormone levels is mandatory for either improvement of quality of life, alleviation of symptoms, and in some cases to potentially prolong survival rates. By different mechanisms, mitotane treatment can already result in some control of hormone levels (see the 'Adjuvant treatment' section). Adrenal steroidogenesis inhibitors like ketoconazole or metyrapone (alone or in combination; Corcuff et al. 2015) can also be used, or more rarely aminoglutethimide or etomidate (Creemers et al. 2015). Mifepristone, a glucocorticoid receptor antagonist, is another treatment modality for excess cortisol levels (Fleseriu et al. 2012). However, there are still no parameters to monitor and guide treatment with mifepristone.

To control androgen effects in women with androgensecreting tumors and mineralocorticoid effects in patients with mineralocorticoid-secreting tumors, spironolactone can be administered (Hunter \& Carek 2003). Monitoring of the patient parameters is important in all cases, considering the risk on adrenal insufficiency.

\section{Future directions and pathway driven therapies}

As previously discussed, extensive effort has been made with different genomic approaches, like CGH, gene expression arrays, methylation analysis and whole genome sequencing, to identify driver mutations and altered signaling pathways in ACC. Since ACC is a very heterogeneous disease with multiple genetic hits affecting different signaling pathways, several therapeutic targets have been identified in different pathways, which are described in the following sections.

IGF-mTOR pathway Familial forms of ACC have enabled identification of IGF2 overexpression in ACCs. Nonetheless, for a long time there has been debate about the role of IGF2 in progression of ACC and consequently its utility as a therapeutic target. Guillaud-Bataille et al. (2014) confirmed the active role of IGF2 on adrenocortical tumor growth in ACC cells by knockdown of IGF2. In this study, ACCs expressing low levels of IGF2 showed higher levels of other growth factors (e.g. FGF9, PDGFA) compared to ACCs that expressed high levels of IGF2, suggesting alternative growth promoting pathways driving ACC pathogenesis. Abnormal activation of the insulinlike growth factor receptor 1 (IGFR1) has also been observed in ACCs (Weber et al. 1997). Based on these findings, and in vitro and preclinical studies with promising results, targeting the IGF pathway had aroused high expectations (Barlaskar et al. 2009). Linsitinib (OSI-906) was the first IGFR1 blocker that reached a phase III trial, but unfortunately did not show an increased overall survival compared to placebo (Fassnacht et al. 2015). Table 5 shows that various clinical studies mainly show disappointing results. A potential explanation can be found in compensatory activation of other growth promoting pathways. Important future considerations are reconsideration of the dosing strategy and efforts to identify potential responders to IGF targeted therapies. Combination therapy with other targeting drugs could be considered.

The role of the mammalian target of rapamycin (mTOR), a downstream effector of IGF2, has been investigated in adrenal tumors by several studies, and mTOR appeared to be a potential therapeutic target in a subset of patients with ACC (Table 5; De Martino et al. 2014). Doghman et al. (2010) reported for the first time involvement of miRNAs in regulation of mTOR signaling in childhood adrenocortical tumors. Targeting mTOR signaling by everolimus caused tumor cell growth reduction in vitro and in mouse xenografts (Doghman et al. 2010). Preclinical studies support the idea that mTOR inhibitors can upregulate AKT phosphorylation in tumor tissue (Hay \& Sonenberg 2004, O'Reilly et al. 2006, Wan et al. 2007, Liu et al. 2009). To address and circumvent the

Published by Bioscientifica Ltd. 


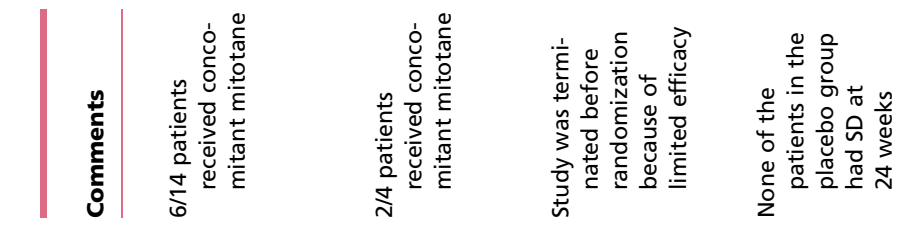

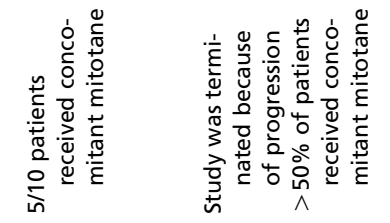

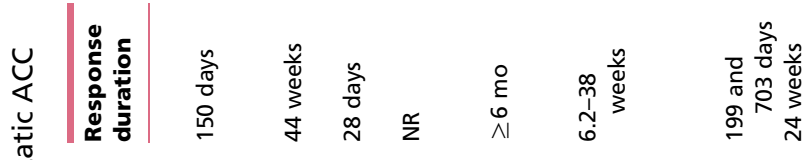

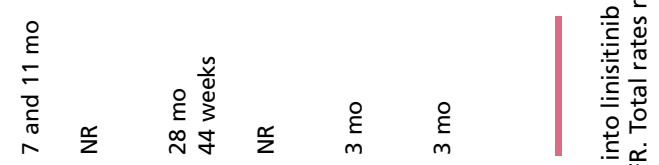

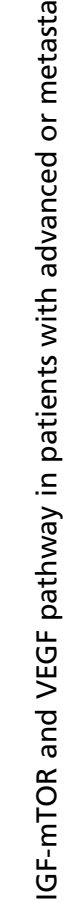

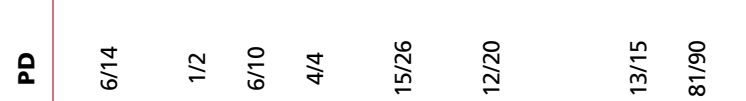

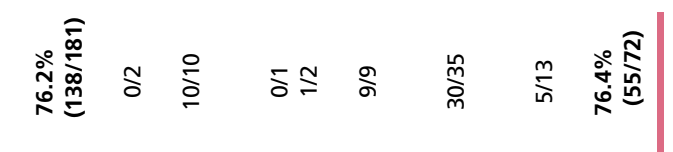

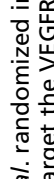

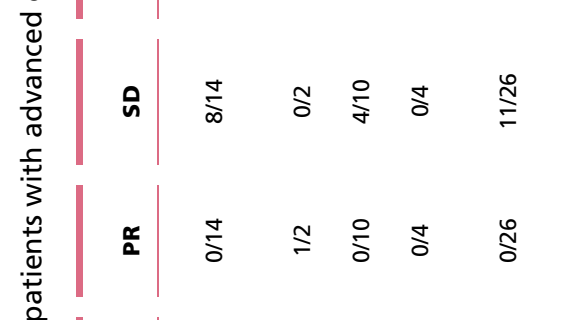

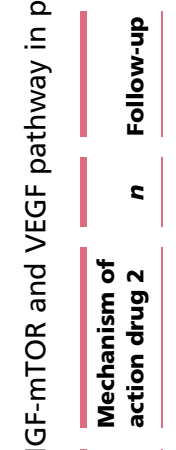

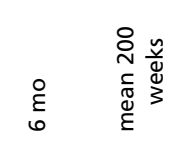

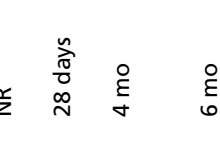

$\stackrel{n}{0} \frac{8}{6}$

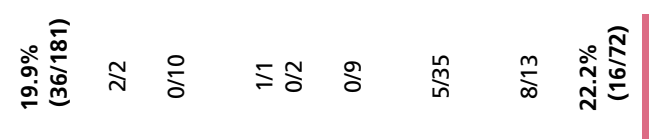

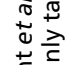

징

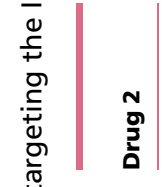

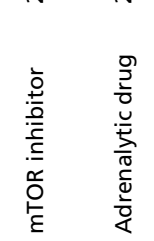

$\stackrel{\circ}{\circ}$

$\stackrel{n}{\sim} \frac{\circ}{m}$

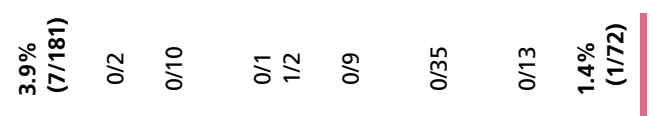

氙萄

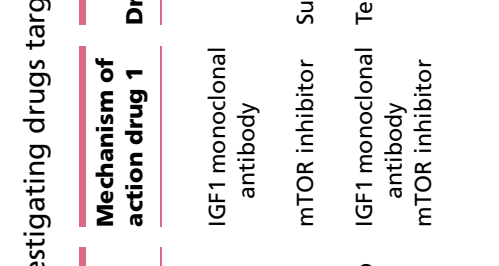

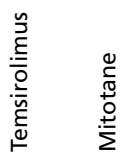

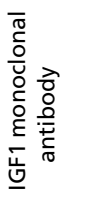

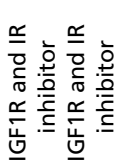

$\stackrel{\bar{\infty}}{\circ}$

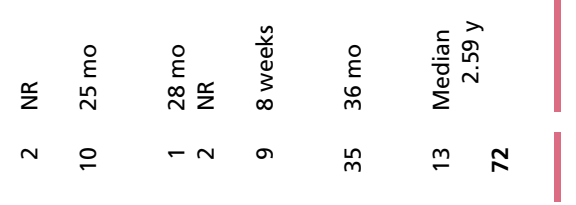

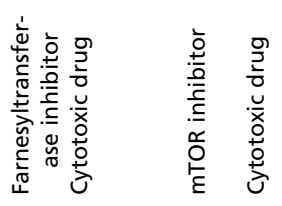

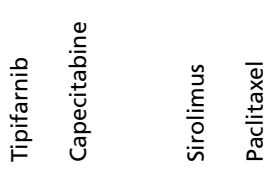

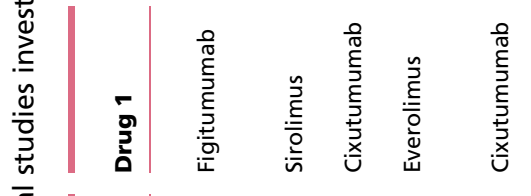

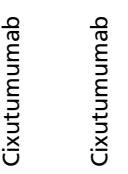

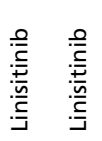

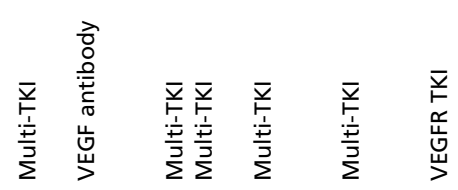

응

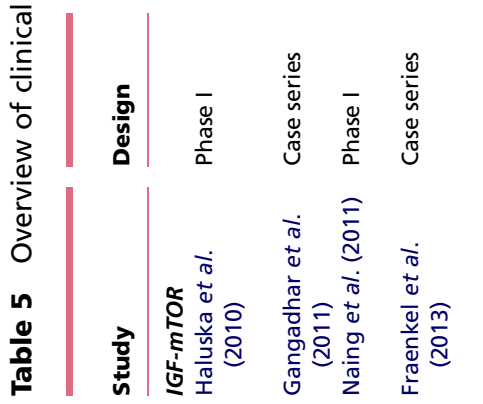

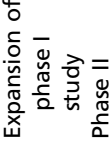

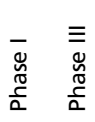

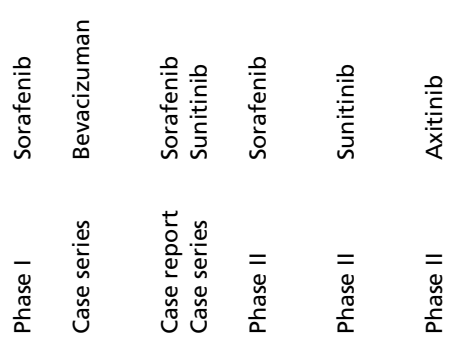

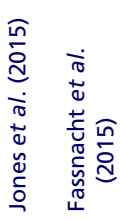

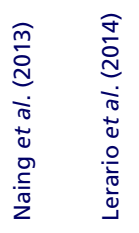

商离

啇

$\frac{0}{4} \frac{0}{0}$

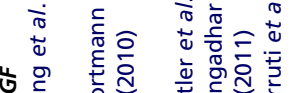

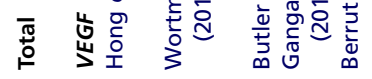

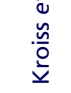

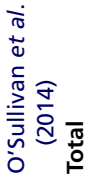


problem of induction of upstream receptor tyrosine kinase signaling, Doghman \& Lalli (2012) showed that a PI3K/mTOR dual inhibitor (NVP-BEZ235) significantly inhibited ACC cell proliferation. Phosphatidylinositol 3-kinase (PI3K) is a downstream signaling pathway. NVPBEZ235 antagonized rebound AKT activation, but induced ERK phosphorylation. In this light, the ERK inhibitor FR180204 in combination with NVP-BEZ235, synergistically inhibited ACC cell proliferation (Doghman \& Lalli 2012). IGFs on the other hand can activate escape mechanisms from mTOR inhibitors by stimulation of AKT or ERK activation (De Martino et al. 2012). This finding demonstrates the potential benefit and rationale for combination of an IGF1R antagonist with an mTOR inhibitor. De Martino et al. showed the effect of the mTOR inhibitor sirolimus on basal and IGF2 stimulated ACC cells in vitro. Sirolimus inhibited basal, as well as IGF2-induced, colony formation and colony size of ACC cells (Fig. 4; De Martino et al. 2012). In a phase II study, the combination of cixutumumab, a fully human IGF1 monoclonal antibody directed at IGF1R, with temsirolimus, an mTOR inhibitor, was well tolerated and resulted in prolonged (6-21 months) stable disease in $42 \%$ of the 26 patients with metastatic ACC (Naing et al. 2013).

WNT signaling pathway Activation of the Wnt/ $\beta$ catenin pathway plays an important role in sporadic adrenocortical tumorigenesis (see the 'Molecular markers' section). The most widely investigated Wnt inhibitor is CWP232291, which is currently in a Phase I trial for refractory acute myeloid leukemia (AML) (NCT01398462). CWP232291 can promote $\beta$-catenin degradation. The first results of effectiveness of targeting the Wnt signaling pathway in ACC comes from in vitro inhibition of ACC cell proliferation by the small-molecule inhibitor PKF115-584
(Doghman et al. 2008). Gaujoux et al. showed that $\beta$-catenin silencing caused decreased cell proliferation, alterations in the cell cycle and increased apoptosis in adrenocortical cancer cells in vitro (Gaujoux et al. 2013). Clinical trials with Wnt inhibitors in ACC have not yet been performed.

Angiogenesis Angiogenesis is an important feature of tumorigenesis. Expression of vascular endothelial growth factor (VEGF), as well as its receptor (VEGFR), have been shown to be increased in ACC tumor tissue (Zacharieva et al. 2004, de Fraipont et al. 2005, Xu et al. 2011). In other types of cancer encouraging results have been achieved with VEGF inhibitor treatment. Several studies have been undertaken with VEGFR inhibitors in patients with ACC (Table 5). Three phase II studies evaluated sorafenib in combination with paclitaxel, sunitinib or axitinib respectively (Berruti et al. 2012, Kroiss et al. 2012, O'Sullivan et al. 2014). Sorafenib did not show an anti-tumor effect in patients, whereas sunitinib and axitinib showed a partial response in 14 and $62 \%$ of the patients respectively (Table 5). The mitotane-induced CYP3A4 increase may limit the therapeutic efficacy of tyrosine kinase inhibitors via enhanced drug metabolism (van Erp et al. 2011).

As previously mentioned, there is evidence that monotherapy with tyrosine kinase inhibitors causes compensatory hyperactivation of other signaling pathways, explaining the lack of efficacy in many patients (Stommel et al. 2007). In two ACC cell lines, Lin et al. (2012) confirmed the activation of multiple tyrosine kinases under treatment with sunitinib, with ERK as the most activated tyrosine kinase. In line with this finding, the authors found an additive antiproliferative effect when sunitinib was given in combination with the ERK inhibitor PD98059.
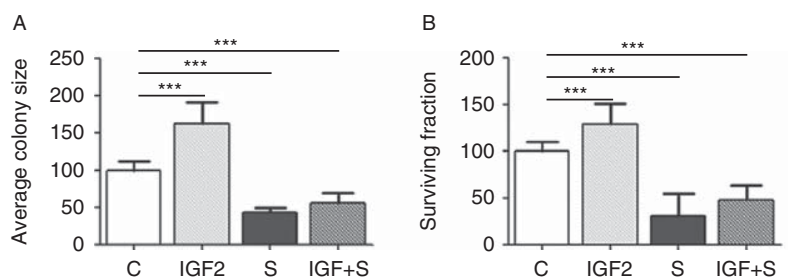

\section{Figure 4}

Effects of 3-week treatment with IGF2 $\left(10^{-8} \mathrm{M}\right)$ and/or sirolimus $\left(5 \times 10^{-9} \mathrm{M}\right)$ on colony formation and growth of the human ACC cell line H295. Left panel: IGF2 stimulates $\mathrm{H} 295$ cell proliferation by increasing the average size of colonies (A) as well as the surviving fraction (B). Both these effects are efficiently antagonized by the coadministration of sirolimus. Data are expressed as percentage of control and represent the mean \pm s.D. Control is set as $100 \%$. The right panel (C) shows a representative photograph of the

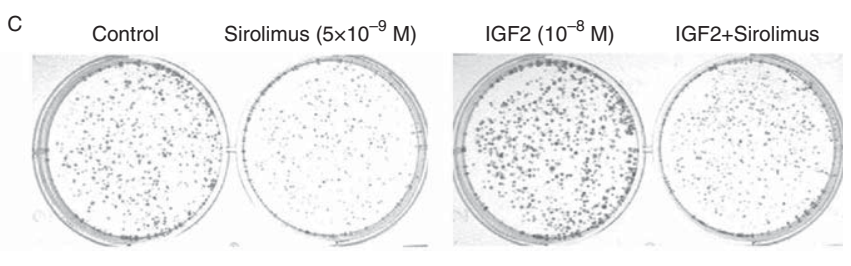

wells containing treated and untreated cells as used to perform colony-forming experiments. *** $\mathrm{P}<0.001$ vs control. Reproduced, with permission, from De Martino MC, van Koetsveld PM, Feelders RA, Sprij-Mooij D, Waaijers M, Lamberts SWJ, de Herder WW, Colao A, Pivonello R \& Hofland LJ (2012) The role of mTOR inhibitors in the inhibition of growth and cortisol secretion in human adrenocortical carcinoma cells. Endocrine-Related Cancer 19 351-364.

Published by Bioscientifica Ltd. 


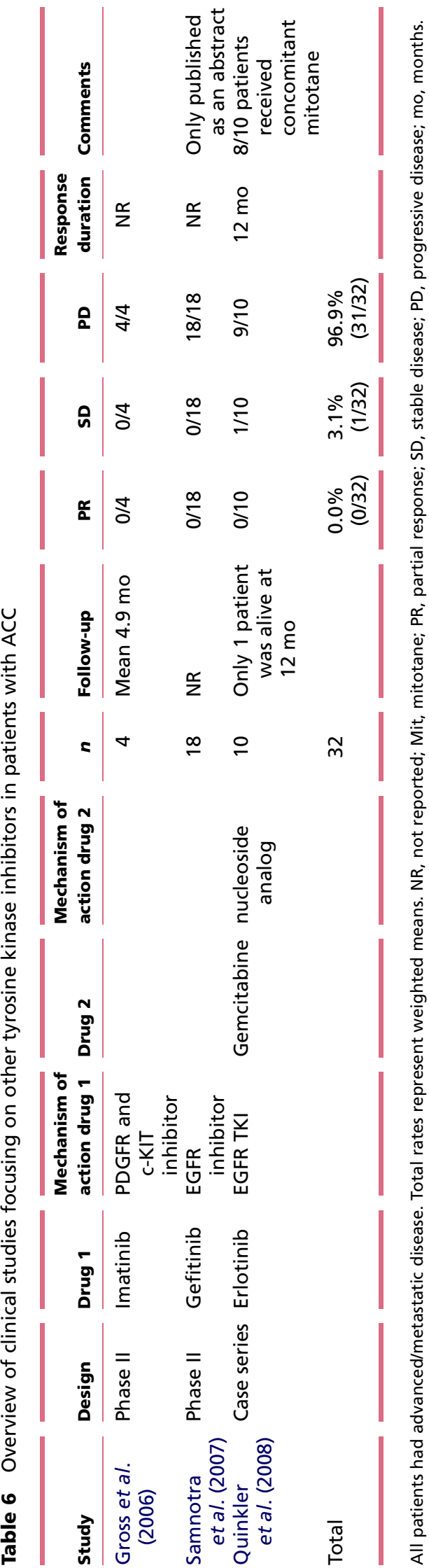

http://erc.endocrinology-journals.org DOI: 10.1530/ERC-15-0452
(C) 2016 Society for Endocrinology Printed in Great Britain
Other tyrosine kinase inhibitors Novel treatment options are primarily based on inhibition of protein kinases involved in signal transduction, not only in the IGF and VEGF pathway. Interest in targeting the EGFR in ACC comes from the fact that not EGFR itself, but the transforming growthfactor $\alpha$ (TGF $\alpha$ ), is expressed at high levels in ACC (Sasano et al. 1994). TGF $\alpha$ can bind the EGFR family. To assess the efficacy of targeting this pathway in ACC, to date two clinical studies have been performed (Table 6; Samnotra et al. 2007, Quinkler et al. 2008). Both did not show significant response (Samnotra et al. 2007, Quinkler et al. 2008). During use of imatinib, a plateletderived growth factor receptor (PDGFR) inhibitor, progressive disease occurred in $4 / 4$ patients with ACC (Table 6; Gross et al. 2006).

Metomidate As already mentioned in the section 'Diagnosis of ACCs', $\left[{ }^{123} \mathrm{I}\right] \mathrm{IMTO}$ has a very high uptake in some adrenocortical lesions (Hahner et al. 2008). The rationale of $\left[{ }^{131} \mathrm{I}\right] \mathrm{IMTO}$ therapy is that patients with high uptake of $\left[{ }^{123}\right.$ I]IMTO in their tumor lesion are suitable for treatment, given the sensitivity of the adrenal to radionuclide therapy and the specific uptake of $\left[{ }^{123} \mathrm{I}\right] \mathrm{IMTO}$ in the tumor (Hahner et al. 2012). Eleven patients receiving up to $20 \mathrm{GBq}\left[{ }^{131} \mathrm{I}\right] \mathrm{IMTO}$ were recently evaluated, of which six patients reached stable disease or even partial response for several months (Hahner et al. 2012).

Chemotherapeutics Research focuses on the investigation of novel chemotherapeutics in preclinical models of ACC. Gemcitabine in vitro demonstrated to be an active cytotoxic agent in ACC cells. Interestingly, efficacy in combination with mitotane was dependent on mitotane sensitivity of the ACC cell line (Germano et al. 2014). In addition, the RRM1 gene appears to play a role in sensitivity to gemcitabine, independent of mitotane (Germano et al. 2014).

MDR/P-Glycoprotein Expression of the multidrug resistance gene 1 (MDR1), which encodes the P-glycoprotein (P-gp), is found in normal adrenals and ACCs (Flynn et al. 1992). The significant chemoresistant character of ACCs has been associated with the presence of P-gp, which actively pumps cytotoxic agents out of the cell (Flynn et al. 1992). Mitotane is in vitro, already at very low concentrations, known to interfere with the MDR1 gene, leading to reversion of chemoresistance (Bates et al. 1991, Gagliano et al. 2014). However, the lack of efficacy of the combination of mitotane with different cytotoxic drugs indicates that resistance to

Published by Bioscientifica Ltd. 
chemotherapy in ACC is mediated by other mechanisms as well. Further studies have to investigate the efficacy of MDR-1 inhibitors in ACC.

\section{Other potential therapeutic targets and com-} pounds Expression of the steroidogenic factor-1 (SF-1) has already been proposed as a diagnostic tool (see the 'Differential gene expression' section). After experiments in transgenic mice, Doghman and colleagues assessed the effect of SF-1 inverse agonists on the SF-1 expressing cell line H295R and the SF-1 negative cell line SW13 (Doghman et al. 2009). Dependent on the class of inhibitors, alkyloxyphenol or isoquinolinone, inhibitory effects were seen in both SF-1 positive and negative cells or only in SF-1 positive H295R cells respectively. These results depict the potential therapeutic possibilities of SF-1 targeting drugs (Doghman et al. 2009).

Van Koetsveld et al. (2013) demonstrated the inhibitory effect of interferon- $\beta$ in vitro on ACC cell lines and primary cultures of human ACC. Interestingly, the sensitivity of ACC cells for mitotane increased if INF- $\beta$ was administered concomitantly (van Koetsveld et al. 2013).

Three other compounds investigated in preclinical ACC models are thiazolidinediones (TZDs), heat shock protein 90 (HSP90) inhibitors, and decitabine, a DNA methyltransferase inhibitor (Betz et al. 2005, Suh et al. 2010, Cerquetti et al. 2011, Huang et al. 2014). All showed inhibition of ACC cell proliferation and other anti-cancer effects. Recovery of two genes (NDUFS 8 and PRDX5) at 11q13, which are known to be silenced in ACC, was given as a possible mechanism of efficacy of decitabine by (Suh et al. 2010).

Jain et al. (2013) investigated the potential of targeting topoisomerase alpha 2 (TOP2A), a gene consistently overexpressed in ACC. By silencing TOP2A in ACC cell lines, it was shown that TOP2A is involved in cellular invasion. Jain et al. (2013) confirmed overexpression of TOP2A in ACC and showed efficacy of several TOP2A inhibitors on proliferation and tumor spheroid size in vitro, with aclarubicin as most promising compound. Aclarubicin is already approved as a second-line therapy for acute myelocytic leukemia.

Based on the finding of overexpression of the interleukin-13 receptor alpha2 (IL13Ra2) in ACCs compared to ACAs and normal adrenals (Jain et al. 2012), a phase I study was recently conducted with systemic interleukin-13-Pseudomonas exotoxin in patients with metastatic ACC (Liu-Chittenden et al. 2015). Overall, $1 / 5$ patients reached stable disease for 5.5 months before disease progression.

\section{Prognostic and predictive markers}

The clinical presentation of patients with ACC as well as the biological behavior of ACCs can be very heterogeneous. Research focuses on the identification of subpopulations of patients in which certain therapies can be effective and increase survival rates. There is an urgent need for markers to improve outcome stratification in patients with ACC. In addition, identifying patients who will respond to treatment will prevent overtreatment, unnecessary adverse effects, and will safe costs. To date, several potential factors have been identified for these two purposes.

Transcriptome studies have not only focused on discriminating adrenal adenomas from carcinomas, but also on understanding the pathophysiology and finding prognostic markers for patients with ACC. Two subgroups have been reported based on transcriptome characteristics: cluster $\mathrm{C} 1 \mathrm{~A}$ and cluster $\mathrm{C} 1 \mathrm{~B}$, the latter one with a remarkable better 5 -years survival rate (20 vs $91 \%$ ) (de Reynies et al. 2009, Giordano et al. 2009, Laurell et al. 2009, Assie et al. 2010). The clusters included different genes, where for example genes associated with cell cycle predominated in the poor outcome group. Giordano et al. (2009) demonstrated that the poor-outcome group contained mainly tumors with a high histologic grade. Ragazzon et al. (2010) showed that all TP53 and CTNNB1 mutations, the genes with most frequent somatic genetic alteration in ACCs, were exclusively observed in the pooroutcome (C1A) ACC group. The poor prognosis group was further divided into three subgroups, with inactivated p53 (C1A-p53), activated $\beta$-catenin (C1A- $\beta$-catenin) and one with a still unidentified molecular alteration (C1A-X) (Ragazzon et al. 2010). Validation of these microarraybased prognostic factors is required. Assie et al. (2014) recently reported, in a study integrating different genomic approaches, that also DNA methylation and microRNAs were different in the $\mathrm{C} 1 \mathrm{~A}$ and $\mathrm{C} 1 \mathrm{~B}$ group. A higher number of mutations was also correlated with a worse 5-year survival rate, higher WS and higher ENSAT stage. Correlation of TOP2A, Ki67, EXH2 and cyclin B1 staining with overall survival was validated by Ip et al. (2015) whereas BARD1 was a newly identified prognostic factor in this study.

Barreau et al. (2013) made the first correlation between DNA methylation levels and patient outcome in ACC. Unsupervised clustering of DNA methylation profiles identified two groups of carcinomas, one with a higher methylation compared to ACAs, which was termed the CpG island methylation phenotype (CIMP) group. CIMP had already been reported in other types of cancer, like

Published by Bioscientifica Ltd 
colorectal cancer (Toyota et al. 1999). The CIMP group was further divided into two subgroups, with different levels of methylation (CIMP-high and CIMP-low; Barreau et al. 2013), which was confirmed by Assie et al. (2014). Hypermethylation was associated with a poor survival. Interestingly, the two subgroups of ACC with poor prognosis presenting with a molecular signature (C1Ap53 and C1A-x), showed a CIMP. In contrast, in the third poor prognosis subgroup (C1A- $\beta$-catenin) and the goodprognosis C1B group, a non-CIMP pattern was observed (Barreau et al. 2013). This finding suggests that different mechanisms are responsible for the differential transcriptome classification. The fact that not all poor prognosis groups show a CIMP could potentially mean that the prognostic value of methylation patterns is less effective compared to gene expression.

Other factors which are reported to associate with poor prognosis in patients with ACC include overexpression of the pituitary tumor transforming gene 1 (PTTG) (Demeure et al. 2013), low expression of the transforming growth factor $\beta$ signaling mediator SMAD and diminished expression of GATA-6 (Parviainen et al. 2013), and cyclin E overproduction (Tissier et al. 2004).

Two reports with a total of 274 patients suggested that patients with cortisol secreting ACCs showed decreased overall survival (Berruti et al. 2005, Abiven et al. 2006). In the study of Abiven et al. (2006), disease-free survival in patients with cortisol-secreting tumors did increase after treatment with mitotane postsurgery, whereas this was not the case in the whole population. The same tendency was reported by Bertherat et al. (2007). Berruti et al. found in a total of 524 patients a correlation between cortisol excess and recurrence-free survival and overall survival, independent of mitotane use (Berruti et al. 2014).

Recently, several studies have identified potential factors associated with response to mitotane, such as CYP2W1 (Ronchi et al. 2014b). Patients with tumors that had CYP2W1 immunoreactivity showed, when adjusted for ENSAT stage, a longer overall survival and time to progression when treated with mitotane monotherapy. This difference was not present in patients who only underwent follow-up (Ronchi et al. 2014b). Ribonucleotide reductase large subunit 1 (RRM1) gene expression was associated with a shorter disease-free survival and overall survival (Volante et al. 2012). Thereby, patients with low RRM1 expression who received adjuvant mitotane had a significantly longer disease-free survival compared to patients who only received follow-up, whereas this was not the case in patients with high RRM1 expression. As a possible mechanism, Germano et al. (2015) showed that the RRM1 gene interferes with mitotane metabolism in ACC cells. Ronchi et al. (2009) investigated protein expression of excision repair cross complementing group 1 (ERCC1) as a predictor for response to platinum-based chemotherapy in patients with ACC. High ERCC1 expression was correlated with a worse overall survival in patients treated with platinum-based chemotherapy.

\section{Conclusion}

There have been advances in diagnosis and treatment of ACC over the past years. The efforts mentioned in this review all aim to improve management of ACC and ACC patient care. Nevertheless, ACC remains a disease with a poor prognosis. Larger molecular studies have greatly expanded our knowledge in the field of pathogenesis, (epi)genetic, chromosomal, transcriptome, and molecular aberrations in adrenocortical cancer. These studies have found different molecular phenotypes for benign and malignant adrenocortical tumors. Also, new imaging techniques, specific immunohistochemical markers (e.g. Ki-67 and reticulin staining), and the measurement of urine metabolomics, have been proposed as new diagnostic tools for ACC. Further research is necessary to validate these findings.

From the molecular studies, we can conclude that ACC does not harbor one 'driver', but ACCs are heterogeneous cancers with many different abnormalities compared to ACAs. Studies focusing on prognostic markers now mainly identify large subgroups of patients with different survival rates. These studies, aiming to find prognostic or diagnostic markers, necessitate further validation of the most promising abnormalities in order to be able to extrapolate such large data to the individual patient.

Despite the fact that some in vitro and preclinical data of novel agents are promising, efficacy of targeted therapies in clinical practice have mainly been disappointing. An important consideration is that ACC pathogenesis is considered to be a multi-molecular event and often results in aggressive cancer, making monotherapy unlikely to be effective. As another consequence of the heterogeneity, most of the therapies are only efficient in a subgroup of patients with ACC. Research should focus on identifying patients with response to therapy by performing individualized tumor analysis. The fact that the first large international and multicenter collaborative studies have been conducted recently gives hope for the future as it comes to the recruitment of ACC patients for new clinical trials. These clinical trials may investigate efficacy of new agents or already known compounds for the

Published by Bioscientifica Ltd. 
treatment of ACC. When designing clinical trials in the future, it is crucial to search for well-considered combinations of therapies, taking into account effects of drugs on cellular processes, pharmacokinetics and dynamics, as well as side effects and interactions between compounds.

\section{Declaration of interest}

R A Feelders, L J Hofland, and W W de Herder have received research grants from Ipsen and Novartis.

\section{Funding}

This research did not receive any specific grant from any funding agency in the public, commercial or not-for-profit sector.

\section{Author contribution statement}

All authors significantly contributed to the content of this review.

\section{References}

Abiven G, Coste J, Groussin L, Anract P, Tissier F, Legmann P, Dousset B, Bertagna X \& Bertherat J 2006 Clinical and biological features in the prognosis of adrenocortical cancer: poor outcome of cortisol-secreting tumors in a series of 202 consecutive patients. Journal of Clinical Endocrinology and Metabolism 91 2650-2655. (doi:10.1210/jc.20052730)

Adam P, Hahner S, Hartmann M, Heinrich B, Quinkler M, Willenberg HS, Saeger W, Sbiera S, Schmull S, Voelker HU et al. 2010 Epidermal growth factor receptor in adrenocortical tumors: analysis of gene sequence, protein expression and correlation with clinical outcome. Modern Pathology 23 1596-1604. (doi:10.1038/modpathol.2010.153)

Allolio B \& Fassnacht M 2006 Clinical review: adrenocortical carcinoma: clinical update. Journal of Clinical Endocrinology and Metabolism 91 2027-2037. (doi:10.1210/jc.2005-2639)

Almeida MQ, Soares IC, Ribeiro TC, Fragoso MCBV, Marins LV, Wakamatsu A, Ressio RA, Nishi MY, Jorge AAL, Lerario AM et al. 2010 Steroidogenic factor 1 overexpression and gene amplification are more frequent in adrenocortical tumors from children than from adults. Journal of Clinical Endocrinology and Metabolism 95 1458-1462. (doi:10.1210/jc.2009-2040)

Ameur N, Lacroix L, Motte N, Baudin E, Caillou B, Ducreux M, Elias D, Chanson P, Schlumberger M \& Bidart JM 2009 Mutational status of EGFR, BRAF, PI3KCA and JAK2 genes in endocrine tumors. International Journal of Cancer 124 751-753. (doi:10.1002/ijc.23999)

Arlt W, Biehl M, Taylor AE, Hahner S, Libe R, Hughes BA, Schneider P, Smith DJ, Stiekema H, Krone N et al. 2011 Urine steroid metabolomics as a biomarker tool for detecting malignancy in adrenal tumors. Journal of Clinical Endocrinology and Metabolism 96 3775-3784. (doi:10.1210/jc.2011-1565)

Asare EA, Wang TS, Winchester DP, Mallin K, Kebebew E \& Sturgeon C 2014 A novel staging system for adrenocortical carcinoma better predicts survival in patients with stage I/II disease. Surgery $\mathbf{1 5 6}$ 1378-1385 discussion 1385-1376. (doi:10.1016/j.surg.2014.08.018)

Assie G, Guillaud-Bataille M, Ragazzon B, Bertagna X, Bertherat J \& Clauser E 2010 The pathophysiology, diagnosis and prognosis of adrenocortical tumors revisited by transcriptome analyses. Trends in Endocrinology and Metabolism 21 325-334. (doi:10.1016/j.tem.2009. 12.009)
Assie G, Letouze E, Fassnacht M, Jouinot A, Luscap W, Barreau O, Omeiri H, Rodriguez S, Perlemoine K, Rene-Corail F et al. 2014 Integrated genomic characterization of adrenocortical carcinoma. Nature Genetics 46 607-612. (doi:10.1038/ng.2953)

Aubert S, Wacrenier A, Leroy X, Devos P, Carnaille B, Proye C, Wemeau JL, Lecomte-Houcke M \& Leteurtre E 2002 Weiss system revisited: a clinicopathologic and immunohistochemical study of 49 adrenocortical tumors. American Journal of Surgical Pathology 26 1612-1619. (doi:10.1097/00000478-200212000-00009)

Barlaskar FM, Spalding AC, Heaton JH, Kuick R, Kim AC, Thomas DG, Giordano TJ, Ben-Josef E \& Hammer GD 2009 Preclinical targeting of the type I insulin-like growth factor receptor in adrenocortical carcinoma. Journal of Clinical Endocrinology and Metabolism 94 204-212. (doi:10.1210/jc.2008-1456)

Barreau O, de Reynies A, Wilmot-Roussel H, Guillaud-Bataille M, Auzan C, Rene-Corail F, Tissier F, Dousset B, Bertagna X, Bertherat J et al. 2012 Clinical and pathophysiological implications of chromosomal alterations in adrenocortical tumors: an integrated genomic approach. Journal of Clinical Endocrinology and Metabolism 97 E301-E311. (doi:10.1210/jc.2011-1588)

Barreau O, Assie G, Wilmot-Roussel H, Ragazzon B, Baudry C, Perlemoine K, Rene-Corail F, Bertagna X, Dousset B, Hamzaoui N et al. 2013 Identification of a CpG island methylator phenotype in adrenocortical carcinomas. Journal of Clinical Endocrinology and Metabolism $\mathbf{9 8}$ E174-E184. (doi:10.1210/jc.2012-2993)

Barzon L, Fallo F, Sonino N, Daniele O \& Boscaro M 1997 Adrenocortical carcinoma: experience in 45 patients. Oncology 54 490-496.

Bates SE, Shieh CY, Mickley LA, Dichek HL, Gazdar A, Loriaux DL \& Fojo AT 1991 Mitotane enhances cytotoxicity of chemotherapy in cell lines expressing a multidrug resistance gene (mdr-1/P-glycoprotein) which is also expressed by adrenocortical carcinomas. Journal of Clinical Endocrinology and Metabolism 73 18-29. (doi:10.1210/jcem-73-1-18)

Baudin E, Pellegriti G, Bonnay M, Penfornis A, Laplanche A, Vassal G \& Schlumberger M 2001 Impact of monitoring plasma 1,1-dichlorodiphenildichloroethane (o,p'DDD) levels on the treatment of patients with adrenocortical carcinoma. Cancer 92 1385-1392.

Bellantone R, Ferrante A, Boscherini M, Lombardi CP, Crucitti P, Crucitti F, Favia G, Borrelli D, Boffi L, Capussotti L et al. 1997 Role of reoperation in recurrence of adrenal cortical carcinoma: results from 188 cases collected in the Italian National Registry for Adrenal Cortical Carcinoma. Surgery 122 1212-1218. (doi:10.1016/S0039-6060(97) 90229-4)

Bellantone R, Lombardi CP \& Raffaelli M 2015 What is the appropriate role of minimally invasive vs. open surgery for small adrenocortical cancers? Current Opinion in Oncology 27 44-49. (doi:10.1097/CCO. 0000000000000144)

Berruti A, Terzolo M, Sperone P, Pia A, Della Casa S, Gross DJ, Carnaghi C, Casali P, Porpiglia F, Mantero F et al. 2005 Etoposide, doxorubicin and cisplatin plus mitotane in the treatment of advanced adrenocortical carcinoma: a large prospective phase II trial. Endocrine-Related Cancer 12 657-666. (doi:10.1677/erc.1.01025)

Berruti A, Sperone P, Ferrero A, Germano A, Ardito A, Priola AM, De Francia S, Volante M, Daffara F, Generali D et al. 2012 Phase II study of weekly paclitaxel and sorafenib as second/third-line therapy in patients with adrenocortical carcinoma. European Journal of Endocrinology 166 451-458. (doi:10.1530/EJE-11-0918)

Berruti A, Fassnacht M, Haak H, Else T, Baudin E, Sperone P, Kroiss M, Kerkhofs T, Williams AR, Ardito A et al. 2014 Prognostic role of overt hypercortisolism in completely operated patients with adrenocortical cancer. European Urology 65 832-838. (doi:10.1016/j.eururo.2013. 11.006)

Bertherat J, Coste J \& Bertagna X 2007 Adjuvant mitotane in adrenocortical carcinoma. New England Journal of Medicine 357 1256-1257 author reply 1259. (doi:10.1056/NEJMc076267)

Betz MJ, Shapiro I, Fassnacht M, Hahner S, Reincke M, Beuschlein F \& German and Austrian Adrenal Network 2005 Peroxisome proliferator-

Published by Bioscientifica Ltd 
activated receptor-gamma agonists suppress adrenocortical tumor cell proliferation and induce differentiation. Journal of Clinical Endocrinology and Metabolism 90 3886-3896. (doi:10.1210/jc.2004-1267)

Beuschlein F, Reincke M, Karl M, Travis WD, Jaursch-Hancke C, Abdelhamid S, Chrousos GP \& Allolio B 1994 Clonal composition of human adrenocortical neoplasms. Cancer Research 54 4927-4932.

Beuschlein F, Weigel J, Saeger W, Kroiss M, Wild V, Daffara F, Libe R, Ardito A, Al Ghuzlan A, Quinkler M et al. 2015 Major prognostic role of Ki67 in localized adrenocortical carcinoma after complete resection. Journal of Clinical Endocrinology and Metabolism 100 841-849. (doi:10.1210/jc.2014-3182)

Birch JM, Alston RD, McNally RJ, Evans DG, Kelsey AM, Harris M, Eden OB \& Varley JM 2001 Relative frequency and morphology of cancers in carriers of germline TP53 mutations. Oncogene 20 4621-4628. (doi:10.1038/sj.onc.1204621)

Bisceglia M, Ludovico O, Di Mattia A, Ben-Dor D, Sandbank J, Pasquinelli G, Lau SK \& Weiss LM 2004 Adrenocortical oncocytic tumors: report of 10 cases and review of the literature. International Journal of Surgical Pathology 12 231-243. (doi:10.1177/106689690401200304)

Bodie B, Novick AC, Pontes JE, Straffon RA, Montie JE, Babiak T, Sheeler L \& Schumacher P 1989 The Cleveland Clinic experience with adrenalcortical carcinoma. Journal of Urology 141 257-260.

Boland GW, Blake MA, Hahn PF \& Mayo-Smith WW 2008 Incidental adrenal lesions: principles, techniques, and algorithms for imaging characterization. Radiology 249 756-775. (doi:10.1148/radiol. 2493070976)

Boland GWL, Dwamena BA, Sangwaiya MJ, Goehler AG, Blake MA, Hahn PF, Scott JA \& Kalra MK 2011 Characterization of adrenal masses by using FDG PET: a systematic review and meta-analysis of diagnostic test performance. Radiology 259 117-126. (doi:10.1148/radiol. 11100569)

Butler C, Butler WM \& Rizvi AA 2010 Sustained remission with the kinase inhibitor sorafenib in stage IV metastatic adrenocortical carcinoma. Endocrine Practice 16 441-445.

Caramuta S, Lee L, Ozata DM, Akcakaya P, Xie H, Hoog A, Zedenius J, Backdahl M, Larsson C \& Lui WO 2013 Clinical and functional impact of TARBP2 over-expression in adrenocortical carcinoma. Endocrine-Related Cancer 20 551-564. (doi:10.1530/ERC-13-0098)

Cattoretti G, Becker MHG, Key G, Duchrow M, Schluter C, Galle J \& Gerdes J 1992 Monoclonal-antibodies against recombinant parts of the Ki-67 antigen (Mib-1 and Mib-3) detect proliferating cells in microwave-processed formalin-fixed paraffin sections. Journal of Pathology 168 357-363. (doi:10.1002/path.1711680404)

Cerquetti L, Bucci B, Marchese R, Misiti S, De Paula U, Miceli R, Muleti A, Amendola D, Piergrossi P, Brunetti E et al. 2008 Mitotane increases the radiotherapy inhibitory effect and induces G(2)-arrest in combined treatment on both H295R and SW13 adrenocortical cell line. Endocrine-Related Cancer 15 623-634. (doi:10.1677/erc.1.1315)

Cerquetti L, Sampaoli C, Amendola D, Bucci B, Masuelli L, Marchese R, Misiti S, De Venanzi A, Poggi M, Toscano V et al. 2011 Rosiglitazone induces autophagy in H295R and cell cycle deregulation in SW13 adrenocortical cancer cells. Experimental Cell Research 317 1397-1410. (doi:10.1016/j.yexcr.2011.02.014)

Chabre O, Libe R, Assie G, Barreau O, Bertherat J, Bertagna X, Feige JJ \& Cherradi N 2013 Serum miR-483-5p and miR-195 are predictive of recurrence risk in adrenocortical cancer patients. Endocrine-Related Cancer 20 579-594. (doi:10.1530/ERC-13-0051)

Corcuff JB, Young J, Masquefa-Giraud P, Chanson P, Baudin E \& Tabarin A 2015 Rapid control of severe neoplastic hypercortisolism with metyrapone and ketoconazole. European Journal of Endocrinology 172 473-481. (doi:10.1530/EJE-14-0913)

Creemers SG, Hofland LJ, Lamberts SW \& Feelders RA 2015 Cushing's syndrome: an update on current pharmacotherapy and future directions. Expert Opinion on Pharmacotherapy 16 1829-1844. (doi:10.1517/14656566.2015.1061995)
Das PM \& Singal R 2004 DNA methylation and cancer. Journal of Clinical Oncology 22 4632-4642. (doi:10.1200/JCO.2004.07.151)

Decker RA, Elson P, Hogan TF, Citrin DL, Westring DW, Banerjee TK, Gilchrist KW \& Horton J 1991 Eastern Cooperative Oncology Group study 1879: mitotane and adriamycin in patients with advanced adrenocortical carcinoma. Surgery 110 1006-1013.

de Fraipont F, El Atifi M, Cherradi N, Le Moigne G, Defaye G, Houlgatte R, Bertherat J, Bertagna X, Plouin PF, Baudin E et al. 2005 Gene expression profiling of human adrenocortical tumors using complementary deoxyribonucleic acid microarrays identifies several candidate genes as markers of malignancy. Journal of Clinical Endocrinology and Metabolism 90 1819-1829. (doi:10.1210/jc.2004-1075)

de Krijger RR \& Papathomas TG 2012 Adrenocortical neoplasia: evolving concepts in tumorigenesis with an emphasis on adrenal cortical carcinoma variants. Virchows Archiv 460 9-18. (doi:10.1007/s00428011-1166-y)

Demars J, Le Bouc Y, El-Osta A \& Gicquel C 2011 Epigenetic and genetic mechanisms of abnormal 11p15 genomic imprinting in Silver-Russell and Beckwith-Wiedemann syndromes. Current Medicinal Chemistry 18 1740-1750. (doi:10.2174/092986711795496764)

De Martino MC, van Koetsveld PM, Feelders RA, Sprij-Mooij D, Waaijers M, Lamberts SW, de Herder WW, Colao A, Pivonello R \& Hofland LJ 2012 The role of mTOR inhibitors in the inhibition of growth and cortisol secretion in human adrenocortical carcinoma cells. Endocrine-Related Cancer 19 351-364. (doi:10.1530/ERC-11-0270)

De Martino MC, Al Ghuzlan A, Aubert S, Assie G, Scoazec JY, Leboulleux S, Do Cao C, Libe R, Nozieres C, Lombes M et al. 2013 Molecular screening for a personalized treatment approach in advanced adrenocortical cancer. Journal of Clinical Endocrinology and Metabolism 98 4080-4088. (doi:10.1210/jc.2013-2165)

De Martino MC, Feelders RA, de Herder WW, van Koetsveld PM, Dogan F, Janssen JA, Waaijers AM, Pivonello C, Lamberts SW, Colao A et al. 2014 Characterization of the mTOR pathway in human normal adrenal and adrenocortical tumors. Endocrine-Related Cancer 21 601-613. (doi:10.1530/ERC-13-0112)

Demeure MJ, Coan KE, Grant CS, Komorowski RA, Stephan E, Sinari S, Mount D \& Bussey KJ 2013 PTTG1 overexpression in adrenocortical cancer is associated with poor survival and represents a potential therapeutic target. Surgery 154 1405-1416. (doi:10.1016/j.surg. 2013.06.058)

de Reynies A, Assie G, Rickman DS, Tissier F, Groussin L, Rene-Corrail F, Dousset B, Bertagna X, Clauser E \& Bertherat J 2009 Gene expression profiling reveals a new classification of adrenocortical tumors and identifies molecular predictors of malignancy and survival. Journal of Clinical Oncology 27 1108-1115. (doi:10.1200/JCO.2008.18.5678)

Doghman M \& Lalli E 2012 Efficacy of the novel dual PI3-kinase/mTOR inhibitor NVP-BEZ235 in a preclinical model of adrenocortical carcinoma. Molecular and Cellular Endocrinology 364 101-104. (doi:10.1016/j.mce.2012.08.014)

Doghman M, Karpova T, Rodrigues GA, Arhatte M, De Moura J, Cavalli LR, Virolle V, Barbry P, Zambetti GP, Figueiredo BC et al. 2007 Increased steroidogenic factor-1 dosage triggers adrenocortical cell proliferation and cancer. Molecular Endocrinology 21 2968-2987. (doi:10.1210/me. 2007-0120)

Doghman M, Cazareth J \& Lalli E 2008 The T cell factor/beta-catenin antagonist PKF115-584 inhibits proliferation of adrenocortical carcinoma cells. Journal of Clinical Endocrinology and Metabolism 93 3222-3225. (doi:10.1210/jc.2008-0247)

Doghman M, Cazareth J, Douguet D, Madoux F, Hodder P \& Lalli E 2009 Inhibition of adrenocortical carcinoma cell proliferation by steroidogenic factor-1 inverse agonists. Journal of Clinical Endocrinology and Metabolism 94 2178-2183. (doi:10.1210/jc.2008-2163)

Doghman M, Madoux F, Hodder P \& Lalli E 2010 Identification and characterization of steroidogenic factor-1 inverse agonists. Methods in Enzymology 485 3-23. (doi:10.1016/B978-0-12-381296-4.00001-4) 
Dohna M, Reincke M, Mincheva A, Allolio B, Solinas-Toldo S \& Lichter P 2000 Adrenocortical carcinoma is characterized by a high frequency of chromosomal gains and high-level amplifications. Genes Chromosomes and Cancer 28 145-152. (doi:10.1002/(SICI)1098-2264(200006)28:2< 145::AID-GCC3 > 3.0.CO;2-7)

Duregon E, Volante M, Cappia S, Cuccurullo A, Bisceglia M, Wong DD, Spagnolo DV, Szpak-Ulczok S, Bollito E, Daffara F et al. 2011 Oncocytic adrenocortical tumors: diagnostic algorithm and mitochondrial DNA profile in 27 cases. American Journal of Surgical Pathology 35 1882-1893. (doi:10.1097/PAS.0b013e31822da401)

Duregon E, Fassina A, Volante M, Nesi G, Santi R, Gatti G, Cappellesso R, Dalino Ciaramella P, Ventura L, Gambacorta M et al. 2013a The reticulin algorithm for adrenocortical tumor diagnosis: a multicentric validation study on 245 unpublished cases. American Journal of Surgical Pathology 37 1433-1440. (doi:10.1097/PAS.0b013e31828d387b)

Duregon E, Volante M, Giorcelli J, Terzolo M, Lalli E \& Papotti M 2013b Diagnostic and prognostic role of steroidogenic factor 1 in adrenocortical carcinoma: a validation study focusing on clinical and pathologic correlates. Human Pathology 44 822-828. (doi:10.1016/ j.humpath.2012.07.025)

Else T, Kim AC, Sabolch A, Raymond VM, Kandathil A, Caoili EM, Jolly S, Miller BS, Giordano TJ \& Hammer GD 2014 Adrenocortical carcinoma. Endocrine Reviews 35 282-326. (doi:10.1210/er.2013-1029)

Erickson LA, Jin L, Sebo TJ, Lohse C, Pankratz VS, Kendrick ML, van Heerden JA, Thompson GB, Grant CS \& Lloyd RV 2001 Pathologic features and expression of insulin-like growth factor-2 in adrenocortical neoplasms. Endocrine Pathology 12 429-435.

Faria JF, Goldman SM, Szejnfeld J, Melo H, Kater C, Kenney P, Huayllas MP, Demarchi G, Francisco VV, Andreoni C et al. 2007 Adrenal masses: characterization with in vivo proton MR spectroscopy-initial experience. Radiology 245 788-797. (doi:10.1148/radiol.2453061854)

Fassnacht M \& Allolio B 2009 Clinical management of adrenocortica carcinoma. Best Practice \& Research. Clinical Endocrinology \& Metabolism 23 273-289. (doi:10.1016/j.beem.2008.10.008)

Fassnacht M, Hahner S, Polat B, Koschker AC, Kenn W, Flentje M \& Allolio B 2006 Efficacy of adjuvant radiotherapy of the tumor bed on local recurrence of adrenocortical carcinoma. Journal of Clinical Endocrinology and Metabolism 91 4501-4504. (doi:10.1210/jc.2006-1007)

Fassnacht M, Johanssen S, Quinkler M, Bucsky P, Willenberg HS, Beuschlein F, Terzolo M, Mueller HH, Hahner S, Allolio B et al. 2009 Limited prognostic value of the 2004 International Union Against Cancer staging classification for adrenocortical carcinoma: proposal for a Revised TNM Classification. Cancer 115 243-250. (doi:10.1002/ cncr.24030)

Fassnacht M, Johanssen S, Fenske W, Weismann D, Agha A, Beuschlein F, Fuhrer D, Jurowich C, Quinkler M, Petersenn S et al. 2010 Improved survival in patients with stage II adrenocortical carcinoma followed up prospectively by specialized centers. Journal of Clinical Endocrinology and Metabolism 95 4925-4932. (doi:10.1210/jc.2010-0803)

Fassnacht M, Libe R, Kroiss M \& Allolio B 2011 Adrenocortical carcinoma: a clinician's update. Nature Reviews. Endocrinology 7 323-335. (doi:10.1038/nrendo.2010.235)

Fassnacht M, Terzolo M, Allolio B, Baudin E, Haak H, Berruti A, Welin S, Schade-Brittinger C, Lacroix A, Jarzab B et al. 2012 Combination chemotherapy in advanced adrenocortical carcinoma. New England Journal of Medicine 366 2189-2197. (doi:10.1056/NEJMoa1200966)

Fassnacht M, Kroiss M \& Allolio B 2013 Update in adrenocortical carcinoma. Journal of Clinical Endocrinology and Metabolism $\mathbf{9 8}$ 4551-4564. (doi:10.1210/jc.2013-3020)

Fassnacht M, Berruti A, Baudin E, Demeure MJ, Gilbert J, Haak H, Kroiss M, Quinn DI, Hesseltine E, Ronchi CL et al. 2015 Linsitinib (OSI-906) versus placebo for patients with locally advanced or metastatic adrenocortical carcinoma: a double-blind, randomised, phase 3 study. Lancet Oncology 16 426-435. (doi:10.1016/S1470-2045(15)70081-1)

Figueiredo BC, Stratakis CA, Sandrini R, DeLacerda L, Pianovsky MAD, Giatzakis C, Young HM \& Haddad BR 1999 Comparative genomic hybridization analysis of adrenocortical tumors of childhood. Journal of Clinical Endocrinology and Metabolism 84 1116-1121. (doi:10.1210/ jcem.84.3.5526)

Figueiredo BC, Ribeiro RC, Zambetti G, Haddad B, Pianovsky MD, Pereira RM, DeLacerda L \& Sandrini R 2000 Amplification of 9q34 in childhood adrenocortical tumors: a specific feature unrelated to ethnic origin or living conditions. Brazilian Journal of Medical and Biological Research 33 1217-1224. (doi:10.1590/S0100-879X2000001000012)

Fleseriu M, Biller BM, Findling JW, Molitch ME, Schteingart DE, Gross C \& Investigators SS 2012 Mifepristone, a glucocorticoid receptor antagonist, produces clinical and metabolic benefits in patients with Cushing's syndrome. Journal of Clinical Endocrinology and Metabolism 97 2039-2049. (doi:10.1210/jc.2011-3350)

Flynn SD, Murren JR, Kirby WM, Honig J, Kan L \& Kinder BK 1992 P-glycoprotein expression and multidrug resistance in adrenocortical carcinoma. Surgery 112 981-986.

Fonseca AL, Kugelberg J, Starker LF, Scholl U, Choi M, Hellman P, Akerstrom G, Westin G, Lifton RP, Bjorklund P et al. 2012 Comprehensive DNA methylation analysis of benign and malignant adrenocortical tumors. Genes Chromosomes and Cancer 51 949-960. (doi:10.1002/gcc.21978)

Fraenkel M, Gueorguiev M, Barak D, Salmon A, Grossman AB \& Gross DJ 2013 Everolimus therapy for progressive adrenocortical cancer. Endocrine 44 187-192.

Gagliano T, Gentilin E, Benfini K, Di Pasquale C, Tassinari M, Falletta S, Feo C, Tagliati F, Uberti ED \& Zatelli MC 2014 Mitotane enhances doxorubicin cytotoxic activity by inhibiting P-gp in human adrenocortical carcinoma cells. Endocrine 47 943-951. (doi:10.1007/ s12020-014-0374-z)

Gangadhar TC, Cohen EE, Wu K, Janisch L, Geary D, Kocherginsky M, House LK, Ramirez J, Undevia SD, Maitland ML et al. 2011 Two drug interaction studies of sirolimus in combination with sorafenib or sunitinib in patients with advanced malignancies. Clinical Cancer Research 17 1956-1963.

Gao ZH, Suppola S, Liu J, Heikkila P, Janne J \& Voutilainen R 2002 Association of H19 promoter methylation with the expression of H19 and IGF-II genes in adrenocortical tumors. Journal of Clinical Endocrinology and Metabolism 87 1170-1176. (doi:10.1210/jcem.87.3.8331)

Gatta-Cherifi B, Chabre O, Murat A, Niccoli P, Cardot-Bauters C, Rohmer V, Young J, Delemer B, Du Boullay H, Verger MF et al. 2012 Adrenal involvement in MEN1. Analysis of 715 cases from the Groupe d'etude des Tumeurs Endocrines database. European Journal of Endocrinology 166 269-279. (doi:10.1530/EJE-11-0679)

Gaujoux S, Tissier F, Groussin L, Libe R, Ragazzon B, Launay P, Audebourg A Dousset B, Bertagna X \& Bertherat J 2008 Wnt/beta-catenin and $3^{\prime}, 5^{\prime}$-cyclic adenosine $5^{\prime}$-monophosphate/protein kinase a signaling pathways alterations and somatic beta-catenin gene mutations in the progression of adrenocortical tumors. Journal of Clinical Endocrinology and Metabolism 93 4135-4140. (doi:10.1210/jc.2008-0631)

Gaujoux S, Pinson S, Gimenez-Roqueplo AP, Amar L, Ragazzon B, Launay P, Meatchi T, Libe R, Bertagna X, Audebourg A et al. 2010 Inactivation of the APC gene is constant in adrenocortical tumors from patients with familial adenomatous polyposis but not frequent in sporadic adrenocortical cancers. Clinical Cancer Research 16 5133-5141. (doi:10.1158/ 1078-0432.CCR-10-1497)

Gaujoux S, Hantel C, Launay P, Bonnet S, Perlemoine K, Lefevre L, Guillaud-Bataille M, Beuschlein F, Tissier F, Bertherat J et al. 2013 Silencing mutated beta-catenin inhibits cell proliferation and stimulates apoptosis in the adrenocortical cancer cell line H295R. PLOS ONE 8 e55743. (doi:10.1371/journal.pone.0055743)

Germano A, Rapa I, Volante M, Lo Buono N, Carturan S, Berruti A Terzolo M \& Papotti M 2014 Cytotoxic activity of gemcitabine, alone or in combination with mitotane, in adrenocortical carcinoma cell lines. Molecular and Cellular Endocrinology 382 1-7. (doi:10.1016/j.mce.2013. 08.023)

Published by Bioscientifica Ltd. 
Germano A, Rapa I, Volante M, De Francia S, Migliore C, Berruti A, Papotti M \& Terzolo M 2015 RRM1 modulates mitotane activity in adrenal cancer cells interfering with its metabolization. Molecular and Cellular Endocrinology 401 105-110. (doi:10.1016/j.mce.2014.11.027)

Ghataore L, Chakraborti I, Aylwin SJ, Schulte KM, Dworakowska D, Coskeran P \& Taylor NF 2012 Effects of mitotane treatment on human steroid metabolism: implications for patient management. Endocrine Connections 1 37-47. (doi:10.1530/EC-12-0028)

Gicquel C, Leblond-Francillard M, Bertagna X, Louvel A, Chapuis Y, Luton JP, Girard F \& Le Bouc Y 1994 Clonal analysis of human adrenocortical carcinomas and secreting adenomas. Clinical Endocrinology 40 465-477. (doi:10.1111/j.1365-2265.1994.tb02485.x)

Gicquel C, RaffinSanson ML, Gaston V, Bertagna X, Plouin PF, Schlumberger M, Louvel A, Luton JP \& LeBouc Y 1997 Structural and functional abnormalities at 11 p15 are associated with the malignant phenotype in sporadic adrenocortical tumors: study on a series of 82 tumors. Journal of Clinical Endocrinology \& Metabolism 82 2559-2565.

Gicquel C, Bertagna X, Gaston V, Coste J, Louvel A, Baudin E, Bertherat J, Chapuis Y, Duclos JM, Schlumberger M et al. 2001 Molecular markers and long-term recurrences in a large cohort of patients with sporadic adrenocortical tumors. Cancer Research 61 6762-6767.

Giordano TJ, Thomas DG, Kuick R, Lizyness M, Misek DE, Smith AL, Sanders D, Aljundi RT, Gauger PG, Thompson NW et al. 2003 Distinct transcriptional profiles of adrenocortical tumors uncovered by DNA microarray analysis. American Journal of Pathology 162 521-531. (doi:10.1016/S0002-9440(10)63846-1)

Giordano TJ, Kuick R, Else T, Gauger PG, Vinco M, Bauersfeld J, Sanders D, Thomas DG, Doherty G \& Hammer G 2009 Molecular classification and prognostication of adrenocortical tumors by transcriptome profiling. Clinical Cancer Research 15 668-676. (doi:10.1158/1078-0432.CCR08-1067)

Golden SH, Robinson KA, Saldanha I, Anton B \& Ladenson PW 2009 Clinical review: Prevalence and incidence of endocrine and metabolic disorders in the United States: a comprehensive review. Journal of Clinical Endocrinology and Metabolism 94 1853-1878. (doi:10.1210/ jc.2008-2291)

Gonzalez RJ, Tamm EP, Ng C, Phan AT, Vassilopoulou-Sellin R, Perrier ND, Evans DB \& Lee JE 2007 Response to mitotane predicts outcome in patients with recurrent adrenal cortical carcinoma. Surgery 142 867-874.

Gonzalez KD, Noltner KA, Buzin CH, Gu DQ, Wen-Fong CY, Nguyen VQ, Han JH, Lowstuter K, Longmate J, Sommer SS et al. 2009 Beyond Li-Fraumeni syndrome: clinical characteristics of families with p53 germline mutations. Journal of Clinical Oncology 27 1250-1256. (doi:10.1200/JCO.2008.16.6959)

Grondal S, Eriksson B, Hagenas L, Werner S \& Curstedt T 1990 Steroid profile in urine - a useful tool in the diagnosis and follow-up of adrenocortical carcinoma. Acta Endocrinologica 122 656-663. (doi:10.1530/acta.0.1220656)

Gross DJ, Munter G, Bitan M, Siegal T, Gabizon A, Weitzen R, Merimsky O, Ackerstein A, Salmon A, Sella A et al. 2006 The role of imatinib mesylate (Glivec) for treatment of patients with malignant endocrine tumors positive for c-kit or PDGF-R. Endocrine-Related Cancer 13 535-540. (doi:10.1677/erc.1.01124)

Grubbs EG, Callender GG, Xing Y, Perrier ND, Evans DB, Phan AT \& Lee JE 2010 Recurrence of adrenal cortical carcinoma following resection: surgery alone can achieve results equal to surgery plus mitotane. Annals of Surgical Oncology 17 263-270.

Gruschwitz T, Breza J, Wunderlich H \& Junker K 2010 Improvement of histopathological classification of adrenal gland tumors by genetic differentiation. World Journal of Urology 28 329-334. (doi:10.1007/ s00345-010-0541-7)

Guillaud-Bataille M, Ragazzon B, de Reynies A, Chevalier C, Francillard I, Barreau O, Steunou V, Guillemot J, Tissier F, Rizk-Rabin M et al. 2014 IGF2 promotes growth of adrenocortical carcinoma cells, but its overexpression does not modify phenotypic and molecular features of adrenocortical carcinoma. PLOS ONE 9 e103744. (doi:10.1371/journal. pone.0103744)

Gust L, Taieb D, Beliard A, Barlier A, Morange I, de Micco C, Henry JF \& Sebag F 2012 Preoperative 18F-FDG uptake is strongly correlated with malignancy, Weiss score, and molecular markers of aggressiveness in adrenal cortical tumors. World Journal of Surgery 36 1406-1410. (doi:10.1007/s00268-011-1374-2)

Haak HR, Hermans J, van de Velde CJ, Lentjes EG, Goslings BM, Fleuren GJ \& Krans HM 1994 Optimal treatment of adrenocortical carcinoma with mitotane: results in a consecutive series of 96 patients. British Journal of Cancer 69 947-951.

Habra MA, Ejaz S, Feng L, Das P, Deniz F, Grubbs EG, Phan A, Waguespack SG, Ayala-Ramirez M, Jimenez C et al. 2013 A retrospective cohort analysis of the efficacy of adjuvant radiotherapy after primary surgical resection in patients with adrenocortical carcinoma. Journal of Clinical Endocrinology and Metabolism 98 192-197. (doi:10.1210/jc. 2012-2367)

Hahner S, Stuermer A, Kreissl M, Reiners C, Fassnacht M, Haenscheid H, Beuschlein F, Zink M, Lang K, Allolio B et al. 2008 [I-123]iodometomidate for molecular imaging of adrenocortical cytochrome P450 family 11B enzymes. Journal of Clinical Endocrinology and Metabolism 93 2358-2365. (doi:10.1210/jc.2008-0050)

Hahner S, Kreissl MC, Fassnacht M, Haenscheid H, Knoedler P, Lang K, Buck AK, Reiners C, Allolio B \& Schirbel A 2012 [131I]iodometomidate for targeted radionuclide therapy of advanced adrenocortical carcinoma. Journal of Clinical Endocrinology and Metabolism 97 914-922. (doi:10.1210/jc.2011-2765)

Hahner S, Kreissl MC, Fassnacht M, Haenscheid H, Bock S, Verburg FA, Knoedler P, Lang K, Reiners C, Buck AK et al. 2013 Functional characterization of adrenal lesions using [123I]IMTO-SPECT/CT. Journal of Clinical Endocrinology and Metabolism 98 1508-1518. (doi:10.1210/jc.2012-3045)

Haluska P, Worden F, Olmos D, Yin DH, Schteingart D, Batzel GN, Paccagnella ML, de Bono JS, Gualberto A \& Hammer GD 2010 Safety, tolerability, and pharmacokinetics of the anti-IGF-1R monoclonal antibody figitumumab in patients with refractory adrenocortical carcinoma. Cancer Chemotherapy and Pharmacology 65 765-773.

Hao HX, Xie Y, Zhang Y, Charlat O, Oster E, Avello M, Lei H, Mickanin C, Liu D, Ruffner H et al. 2012 ZNRF3 promotes Wnt receptor turnover in an R-spondin-sensitive manner. Nature 485 195-200. (doi:10.1038/ nature11019)

Hay N \& Sonenberg N 2004 Upstream and downstream of mTOR. Genes Development 18 1926-1945. (doi:10.1101/gad.1212704)

Hennings J, Lindhe O, Bergstrom M, Langstrom B, Sundin A \& Hellman P 2006 [11C]metomidate positron emission tomography of adrenocortical tumors in correlation with histopathological findings. Journal of Clinical Endocrinology and Metabolism 91 1410-1414. (doi:10.1210/jc.2005-2273)

Hermsen IGC, Groenen YE, Dercksen MW, Theuws J \& Haak HR 2010 Response to radiation therapy in adrenocortical carcinoma. Journal of Endocrinological Investigation 33 712-714. (doi:10.1007/BF03346675)

Hermsen IG, Fassnacht M, Terzolo M, Houterman S, den Hartigh J, Leboulleux S, Daffara F, Berruti A, Chadarevian R, Schlumberger M et al. 2011 Plasma Concentrations of o,p ' DDD, o,p ' DDA, and o,p ' DDE as Predictors of Tumor Response to Mitotane in Adrenocortical Carcinoma: Results of a Retrospective ENS@T Multicenter Study. Journal of Clinical Endocrinology and Metabolism 96 1844-1851. (doi:10.1210/jc.2010-2676)

Ho J, Turkbey B, Edgerly M, Alimchandani M, Quezado M, Camphausen K, Fojo T \& Kaushal A 2013 Role of radiotherapy in adrenocortical carcinoma. Cancer Journal 19 288-294. (doi:10.1097/PPO. Ob013e31829e3221)

Hong DS, Sebti SM, Newman RA, Blaskovich MA, Ye L, Gagel RF, Moulder S, Wheler JJ, Naing A, Tannir NM et al. 2009 Phase I trial of a combination of the multikinase inhibitor sorafenib and the farnesyltransferase 
inhibitor tipifarnib in advanced malignancies. Clinical Cancer Research 15 7061-7068.

Huang J, Sun C, Zhang T, Pan L, Wang S, He Q \& Li D 2014 Potent antitumor activity of HSP90 inhibitor AUY922 in adrenocortical carcinoma. Tumour Biology 35 8193-8199. (doi:10.1007/s13277-0142063-1)

Hunter MH \& Carek PJ 2003 Evaluation and treatment of women with hirsutism. American Family Physician 67 2565-2572.

Icard P, Goudet P, Charpenay C, Andreassian B, Carnaille B, Chapuis Y, Cougard P, Henry JF \& Proye C 2001 Adrenocortical carcinomas: surgical trends and results of a 253-patient series from the French Association of Endocrine Surgeons study group. World Journal of Surgery 25 891-897. (doi:10.1007/s00268-001-0047-y)

Igaz P, Igaz I, Nagy Z, Nyiro G, Szabo PM, Falus A, Patocs A \& Racz K 2015 MicroRNAs in adrenal tumors: relevance for pathogenesis, diagnosis, and therapy. Cellular and Molecular Life Sciences 72 417-428. (doi:10.1007/s00018-014-1752-7)

Iino K, Sasano H, Yabuki N, Oki Y, Kikuchi A, Yoshimi T \& Nagura H 1997 DNA topoisomerase II alpha and Ki-67 in human adrenocortical neoplasms: a possible marker of differentiation between adenomas and carcinomas. Modern Pathology 10 901-907.

Ilias I, Sahdev A, Reznek RH, Grossman AB \& Pacak K 2007 The optimal imaging of adrenal tumours: a comparison of different methods. Endocrine-Related Cancer 14 587-599. (doi:10.1677/ERC-07-0045)

Ip JC, Pang TC, Glover AR, Soon P, Zhao JT, Clarke S, Robinson BG, Gill AJ \& Sidhu SB 2015 Immunohistochemical validation of overexpressed genes identified by global expression microarrays in adrenocortical carcinoma reveals potential predictive and prognostic biomarkers. Oncologist 20 247-256. (doi:10.1634/theoncologist.2014-0392)

Jain M, Zhang LS, He M, Patterson EE, Nilubol N, Fojo AT, Joshi B, Puri R \& Kebebew E 2012 Interleukin-13 receptor Alpha2 Is a novel therapeutic target for human adrenocortical carcinoma. Cancer 118 5698-5708. (doi:10.1002/cncr.27629)

Jain M, Zhang LS, He M, Zhang YQ, Shen M \& Kebebew E 2013 TOP2A is overexpressed and is a therapeutic target for adrenocortical carcinoma. Endocrine-Related Cancer 20 361-370. (doi:10.1530/ERC-12-0403)

James LA, Kelsey AM, Birch JM \& Varley JM 1999 Highly consistent genetic alterations in childhood adrenocortical tumours detected by comparative genomic hybridization. British Journal of Cancer 81 300-304. (doi:10.1038/sj.bjc.6990691)

Johnson PT, Horton KM \& Fishman EK 2009 Adrenal mass imaging with multidetector CT: pathologic conditions, pearls, and pitfalls. Radiographics 29 1333-1351. (doi:10.1148/rg.295095027)

Jones RL, Kim ES, Nava-Parada P, Alam S, Johnson FM, Stephens AW, Simantov R, Poondru S, Gedrich R, Lippman SM et al. 2015 Phase I study of intermittent oral dosing of the insulin-like growth factor- 1 and insulin receptors inhibitor OSI-906 in patients with advanced solid tumors. Clinical Cancer Research 21 693-700.

Juhlin CC, Goh G, Healy JM, Fonseca AL, Scholl UI, Stenman A, Kunstman JW, Brown TC, Overton JD, Mane SM et al. 2015 Wholeexome sequencing characterizes the landscape of somatic mutations and copy number alterations in adrenocortical carcinoma. Journal of Clinical Endocrinology and Metabolism 100 E493-E502. (doi:10.1210/jc. 2014-3282)

Karamurzin Y, Zeng ZS, Stadler ZK, Zhang LY, Ouansafi I, Al-Ahmadie HA, Sempoux C, Saltz LB, Soslow RA, O'Reilly EM et al. 2012 Unusual DNA mismatch repair-deficient tumors in Lynch syndrome: a report of new cases and review of the literature. Human Pathology 43 1677-1687. (doi:10.1016/j.humpath.2011.12.012)

Kebebew E, Reiff E, Duh QY, Clark OH \& McMillan A 2006 Extent of disease at presentation and outcome for adrenocortical carcinoma: Have we made progress? World Journal of Surgery 30 872-878. (doi:10.1007/ s00268-005-0329-x)

Kerkhofs TM, Verhoeven RH, Bonjer HJ, van Dijkum EJ, Vriens MR, De Vries J, Van Eijck CH, Bonsing BA, Van de Poll-Franse LV, Haak HR et al. 2013a Surgery for adrenocortical carcinoma in The Netherlands: analysis of the national cancer registry data. European Journal of Endocrinology 169 83-89. (doi:10.1530/EJE-13-0142)

Kerkhofs TM, Verhoeven RH, Van der Zwan JM, Dieleman J, Kerstens MN, Links TP, Van de Poll-Franse LV \& Haak HR 2013b Adrenocortical carcinoma: a population-based study on incidence and survival in the Netherlands since 1993. European Journal of Cancer 49 2579-2586. (doi:10.1016/j.ejca.2013.02.034)

Kerkhofs TM, Baudin E, Terzolo M, Allolio B, Chadarevian R, Mueller HH, Skogseid B, Leboulleux S, Mantero F, Haak HR \& Fassnacht M 2013c Comparison of two mitotane starting dose regimens in patients with advanced adrenocortical carcinoma. Journal of Clinical Endocrinology and Metabolism 98 4759-4767. (doi:10.1210/jc.2013-2281)

Kerkhofs TM, Kerstens MN, Kema IP, Willems TP \& Haak HR 2015 Diagnostic value of urinary steroid profiling in the evaluation of adrenal tumors. Hormones \& Cancer 6 168-175. (doi:10.1007/s12672015-0224-3)

Kjellman M, Kallioniemi OP, Karhu R, Hoog A, Farnebo LO, Auer G, Larsson C \& Backdahl M 1996 Genetic aberrations in adrenocortical tumors detected using comparative genomic hybridization correlate with tumor size and malignancy. Cancer Research 56 4219-4223.

Kleihues P, Schauble B, zur Hausen A, Esteve J \& Ohgaki H 1997 Tumors associated with p53 germline mutations: a synopsis of 91 families. American Journal of Pathology 150 1-13.

Kotoula V, Sozopoulos E, Litsiou H, Fanourakis G, Koletsa T, Voutsinas G, Tseleni-Balafouta S, Mitsiades CS, Wellmann A \& Mitsiades N 2009 Mutational analysis of the BRAF, RAS and EGFR genes in human adrenocortical carcinomas. Endocrine-Related Cancer 16 565-572. (doi:10.1677/ERC-08-0101)

Kreissl MC, Schirbel A, Fassnacht M, Haenscheid H, Verburg FA, Bock S, Saeger W, Knoedler P, Reiners C, Buck AK et al. 2013 [(1)(2)(3)I] Iodometomidate imaging in adrenocortical carcinoma. Journal of Clinical Endocrinology and Metabolism 98 2755-2764. (doi:10.1210/ jc.2012-3261)

Kroiss M, Quinkler M, Lutz WK, Allolio B \& Fassnacht M 2011 Drug interactions with mitotane by induction of CYP3A4 metabolism in the clinical management of adrenocortical carcinoma. Clinical Endocrinology 75 585-591. (doi:10.1111/j.1365-2265.2011.04214.x)

Kroiss M, Quinkler M, Johanssen S, van Erp NP, Lankheet N, Pollinger A, Laubner K, Strasburger CJ, Hahner S, Muller HH et al. 2012 Sunitinib in refractory adrenocortical carcinoma: a phase II, single-arm, open-label trial. Journal of Clinical Endocrinology and Metabolism 97 3495-3503. (doi:10.1210/jc.2012-1419)

Lacroix A 2010 Approach to the patient with adrenocortical carcinoma. Journal of Clinical Endocrinology and Metabolism 95 4812-4822. (doi:10.1210/jc.2010-0990)

Lafemina J \& Brennan MF 2012 Adrenocortical carcinoma: past, present, and future. Journal of Surgical Oncology 106 586-594. (doi:10.1002/jso. 23112)

Lapunzina P 2005 Risk of tumorigenesis in overgrowth syndromes: a comprehensive review. American Journal of Medical Genetics. Part C, Seminars in Medical Genetics 137C 53-71. (doi:10.1002/ajmg.c.30064)

Lau SK \& Weiss LM 2009 The Weiss system for evaluating adrenocortical neoplasms: 25 years later. Human Pathology 40 757-768. (doi:10.1016/ j.humpath.2009.03.010)

Laurell C, Velazquez-Fernandez D, Lindsten K, Juhlin C, Enberg U, Geli J, Hoog A, Kjellman M, Lundeberg J, Hamberger B et al. 2009 Transcriptional profiling enables molecular classification of adrenocortical tumours. European Journal of Endocrinology 161 141-152. (doi:10.1530/EJE-09-0068)

Leboulleux S, Dromain C, Bonniaud G, Auperin A, Caillou B, Lumbroso J, Sigal R, Baudin E \& Schlumberger M 2006 Diagnostic and prognostic value of 18-fluorodeoxyglucose positron emission tomography in adrenocortical carcinoma: a prospective comparison with computed tomography. Journal of Clinical Endocrinology and Metabolism 91 920-925. (doi:10.1210/jc.2005-1540) 
Leboulleux S, Deandreis D, Escourrou C, Al Ghuzlan A, Bidault F, Auperin A, Travagli JP, Lumbroso J, Schlumberger M \& Baudin E 2011 Fluorodesoxyglucose uptake in the remaining adrenal glands during the follow-up of patients with adrenocortical carcinoma: do not consider it as malignancy. European Journal of Endocrinology 164 89-94. (doi:10.1530/EJE-10-0666)

Lerario AM, Worden FP, Ramm CA, Hesseltine EA, Stadler WM, Else T, Shah MH, Agamah E, Rao K \& Hammer GD 2014 The combination of insulinlike growth factor receptor 1 (IGF1R) antibody cixutumumab and mitotane as a first-line therapy for patients with recurrent/metastatic adrenocortical carcinoma: a multi-institutional NCI-sponsored trial. Hormones \& Cancer 5 232-239. (doi:10.1007/s12672-014-0182-1)

Libe R, Groussin L, Tissier F, Elie C, Rene-Corail F, Fratticci A, Jullian E, Beck-Peccoz P, Bertagna X, Gicquel C et al. 2007 Somatic TP53 mutations are relatively rare among adrenocortical cancers with the frequent 17p13 loss of heterozygosity. Clinical Cancer Research $\mathbf{1 3}$ 844-850. (doi:10.1158/1078-0432.CCR-06-2085)

Lin CI, Whang EE, Moalem J \& Ruan DT 2012 Strategic combination therapy overcomes tyrosine kinase coactivation in adrenocortical carcinoma. Surgery 152 1045-1050. (doi:10.1016/j.surg.2012.08.035)

Liu P, Cheng H, Roberts TM \& Zhao JJ 2009 Targeting the phosphoinositide 3-kinase pathway in cancer. Nature Reviews. Drug Discovery 8 627-644. (doi:10.1038/nrd2926)

Liu-Chittenden Y, Jain M, Kumar P, Patel D, Aufforth R, Neychev V, Sadowski S, Gara SK, Joshi BH, Cottle-Delisle C et al. 2015 Phase I trial of systemic intravenous infusion of interleukin-13-Pseudomonas exotoxin in patients with metastatic adrenocortical carcinoma. Cancer Medicine 4 1060-1068. (doi:10.1002/cam4.449)

Livhits M, Li N, Yeh MW \& Harari A 2014 Surgery is associated with improved survival for adrenocortical cancer, even in metastatic disease. Surgery 156 1531-1541. (doi:10.1016/j.surg.2014.08.047)

Lughezzani G, Sun M, Perrotte P, Jeldres C, Alasker A, Isbarn H, Budaus L, Shariat SF, Guazzoni G, Montorsi F et al. 2010 The European Network for the Study of Adrenal Tumors staging system is prognostically superior to the international union against cancer-staging system: a North American validation. European Journal of Cancer 46 713-719. (doi:10.1016/j.ejca.2009.12.007)

Luton JP, Cerdas S, Billaud L, Thomas G, Guilhaume B, Bertagna X, Laudat MH, Louvel A, Chapuis Y, Blondeau P et al. 1990 Clinical features of adrenocortical carcinoma, prognostic factors, and the effect of mitotane therapy. New England Journal of Medicine 322 1195-1201.

Malkin D, Li FP, Strong LC, Fraumeni JF Jr, Nelson CE, Kim DH, Kassel J, Gryka MA, Bischoff FZ, Tainsky MA et al. 1990 Germ line p53 mutations in a familial syndrome of breast cancer, sarcomas, and other neoplasms. Science 250 1233-1238. (doi:10.1126/science.1978757)

Malumbres M 2013 miRNAs and cancer: an epigenetics view. Molecular Aspects of Medicine 34 863-874. (doi:10.1016/j.mam.2012.06.005)

Masi G, Lavezzo E, Iacobone M, Favia G, Palu G \& Barzon L 2009 Investigation of BRAF and CTNNB1 activating mutations in adrenocortical tumors. Journal of Endocrinological Investigation 32 597-600. (doi:10.1007/BF03346515)

Medina-Arana V, Delgado L, Gonzalez L, Bravo A, Diaz H, Salido E, Riverol D, Gonzalez-Aguilera JJ \& Fernandez-Peralta AM 2011 Adrenocortical carcinoma, an unusual extracolonic tumor associated with Lynch II syndrome. Familial Cancer 10 265-271. (doi:10.1007/ s10689-010-9416-8)

Minn H, Salonen A, Friberg J, Roivainen A, Viljanen T, Langsjo J, Salmi J, Valimaki M, Nagren K \& Nuutila P 2004 Imaging of adrenal incidentalomas with PET using C-11-metomidate and F-18-FDG. Journal of Nuclear Medicine 45 972-979.

Morimoto R, Satoh F, Murakami O, Suzuki T, Abe T, Tanemoto M, Abe M, Uruno A, Ishidoya S, Arai Y et al. 2008 Immunohistochemistry of a proliferation marker Ki67/MIB1 in adrenocortical carcinomas: Ki67/MIB1 Labeling index is a predictor for recurrence of adrenocortical carcinomas. Endocrine Journal 55 49-55. (doi:10.1507/endocrj. K07-079)
Nader N, Raverot G, Emptoz-Bonneton A, Dechaud H, Bonnay M, Baudin E \& Pugeat M 2006 Mitotane has an estrogenic effect on sex hormonebinding globulin and corticosteroid-binding globulin in humans. Journal of Clinical Endocrinology and Metabolism 91 2165-2170. (doi:10.1210/jc.2005-2157)

Naing A, Kurzrock R, Burger A, Gupta S, Lei X, Busaidy N, Hong D, Chen HX, Doyle LA, Heilbrun LK et al. 2011 Phase I trial of cixutumumab combined with temsirolimus in patients with advanced cancer. Clinical Cancer Research 17 6052-6060. (doi:10.1158/ 1078-0432.CCR-10-2979)

Naing A, LoRusso P, Fu S, Hong D, Chen HX, Doyle LA, Phan AT, Habra MA \& Kurzrock R 2013 Insulin growth factor receptor (IGF-1R) antibody cixutumumab combined with the mTOR inhibitor temsirolimus in patients with metastatic adrenocortical carcinoma. British Journal of Cancer 108 826-830. (doi:10.1038/bjc.2013.46)

Nieman LK 2010 Approach to the patient with an adrenal incidentaloma. Journal of Clinical Endocrinology and Metabolism 95 4106-4113. (doi:10.1210/jc.2010-0457)

Nunes ML, Rault A, Teynie J, Valli N, Guyot M, Gaye D, Belleannee G \& Tabarin A 2010 18F-FDG PET for the identification of adrenocortical carcinomas among indeterminate adrenal tumors at computed tomography scanning. World Journal of Surgery 34 1506-1510. (doi:10.1007/s00268-010-0576-3)

O'Reilly KE, Rojo F, She QB, Solit D, Mills GB, Smith D, Lane H, Hofmann F, Hicklin DJ, Ludwig DL et al. 2006 mTOR inhibition induces upstream receptor tyrosine kinase signaling and activates Akt. Cancer Research 66 1500-1508. (doi:10.1158/0008-5472.CAN-05-2925)

O'Sullivan C, Edgerly M, Velarde M, Wilkerson J, Venkatesan AM, Pittaluga S, Yang SX, Nguyen D, Balasubramaniam S \& Fojo T 2014 The VEGF inhibitor Axitinib has limited effectiveness as a therapy for adrenocortical cancer. Journal of Clinical Endocrinology and Metabolism 99 1291-1297. (doi:10.1210/jc.2013-2298)

Ozata DM, Caramuta S, Velazquez-Fernandez D, Akcakaya P, Xie H, Hoog A, Zedenius J, Backdahl M, Larsson C \& Lui WO 2011 The role of microRNA deregulation in the pathogenesis of adrenocortical carcinoma. Endocrine-Related Cancer 18 643-655. (doi:10.1530/ ERC-11-0082)

Papotti M, Volante M, Duregon E, Delsedime L, Terzolo M, Berruti A \& Rosai J 2010 Adrenocortical tumors with myxoid features: a distinct morphologic and phenotypical variant exhibiting malignant behavior. American Journal of Surgical Pathology 34 973-983. (doi:10.1097/PAS. Ob013e3181e2b726)

Papotti M, Duregon E, Volante M \& McNicol AM 2014 Pathology of the adrenal cortex: a reappraisal of the past 25 years focusing on adrenal cortical tumors. Endocrine Pathology 25 35-48. (doi:10.1007/s12022013-9291-6)

Parviainen H, Schrade A, Kiiveri S, Prunskaite-Hyyrylainen R, Haglund C, Vainio S, Wilson DB, Arola J \& Heikinheimo M 2013 Expression of Wnt and TGF-beta pathway components and key adrenal transcription factors in adrenocortical tumors: association to carcinoma aggressiveness. Pathology, Research and Practice 209 503-509. (doi:10.1016/j.prp. 2013.06.002)

Patel D, Boufraqech M, Jain M, Zhang L, He M, Gesuwan K, Gulati N, Nilubol N, Fojo T \& Kebebew E 2013 MiR-34a and miR-483-5p are candidate serum biomarkers for adrenocortical tumors. Surgery $\mathbf{1 5 4}$ 1224-1228; discussion 1229. (doi:10.1016/j.surg.2013.06.022)

Patterson EE, Holloway AK, Weng J, Fojo T \& Kebebew E 2011 MicroRNA profiling of adrenocortical tumors reveals miR-483 as a marker of malignancy. Cancer 117 1630-1639. (doi:10.1002/cncr.25724)

Pennanen M, Heiskanen I, Sane T, Remes S, Mustonen H, Haglund C \& Arola J 2015 Helsinki score - a novel model for prediction of metastases in adrenocortical carcinomas. Human Pathology 46 404-410. (doi:10.1016/j.humpath.2014.11.015)

Petersenn S, Richter PA, Broemel T, Ritter CO, Deutschbein T, Beil FU, Allolio B, Fassnacht M \& German ACCSG 2015 Computed tomography criteria for discrimination of adrenal adenomas and adrenocortical 
carcinomas: analysis of the German ACC registry. European Journal of Endocrinology 172 415-422. (doi:10.1530/EJE-14-0916)

Pianovski MA, Cavalli LR, Figueiredo BC, Santos SC, Doghman M, Ribeiro RC, Oliveira AG, Michalkiewicz E, Rodrigues GA, Zambetti G et al. 2006 SF-1 overexpression in childhood adrenocortical tumours. European Journal of Cancer 42 1040-1043. (doi:10.1016/j.ejca.2006. 01.022)

Polat B, Fassnacht M, Pfreundner L, Guckenberger M, Bratengeier K, Johanssen S, Kenn W, Hahner S, Allolio B \& Flentje M 2009 Radiotherapy in adrenocortical carcinoma. Cancer 115 2816-2823. (doi:10.1002/cncr.24331)

Poli G, Guasti D, Rapizzi E, Fucci R, Canu L, Bandini A, Cini N, Bani D, Mannelli M \& Luconi M 2013 Morphofunctional effects of mitotane on mitochondria in human adrenocortical cancer cells. Endocrine-Related Cancer 20 537-550. (doi:10.1530/ERC-13-0150)

Pommier RF \& Brennan MF 1992 An eleven-year experience with adrenocortical carcinoma. Surgery 112 963-970; discussion 970-961.

Quinkler M, Hahner S, Wortmann S, Johanssen S, Adam P, Ritter C, Strasburger C, Allolio B \& Fassnacht M 2008 Treatment of advanced adrenocortical carcinoma with erlotinib plus gemcitabine. Journal of Clinical Endocrinology and Metabolism 93 2057-2062. (doi:10.1210/jc. 2007-2564)

Ragazzon B, Libe R, Gaujoux S, Assie G, Fratticci A, Launay P, Clauser E, Bertagna X, Tissier F, de Reynies A et al. 2010 Transcriptome analysis reveals that p53 and beta-catenin alterations occur in a group of aggressive adrenocortical cancers. Cancer Research 70 8276-8281. (doi:10.1158/0008-5472.CAN-10-2014)

Ragazzon B, Libe R, Assie G, Tissier F, Barreau O, Houdayer C, Perlemoine K, Audebourg A, Clauser E, Rene-Corail F et al. 2014 Mass-array screening of frequent mutations in cancers reveals RB1 alterations in aggressive adrenocortical carcinomas. European Journal of Endocrinology $\mathbf{1 7 0}$ 385-391. (doi:10.1530/EJE-13-0778)

Raymond JM, Everett JN \& Furtado LV 2013 Adrenocortical carcinoma is a lynch syndrome-associated cancer. Journal of Clinical Oncology $\mathbf{3 1}$ 3012-3018. (doi:10.1200/JCO.2012.48.0988)

Rechache NS, Wang Y, Stevenson HS, Killian JK, Edelman DC, Merino M, Zhang L, Nilubol N, Stratakis CA, Meltzer PS et al. 2012 DNA methylation profiling identifies global methylation differences and markers of adrenocortical tumors. Journal of Clinical Endocrinology and Metabolism 97 E1004-E1013. (doi:10.1210/jc.2011-3298)

Reincke M, Karl M, Travis WH, Mastorakos G, Allolio B, Linehan HM \& Chrousos GP 1994 p53 mutations in human adrenocortical neoplasms: immunohistochemical and molecular studies. Journal of Clinical Endocrinology and Metabolism 78 790-794. (doi:10.1210/jcem.78.3. 8126158)

Ronchi CL, Sbiera S, Kraus L, Wortmann S, Johanssen S, Adam P, Willenberg HS, Hahner S, Allolio B \& Fassnacht M 2009 Expression of excision repair cross complementing group 1 and prognosis in adrenocortical carcinoma patients treated with platinum-based chemotherapy. Endocrine-Related Cancer 16 907-918. (doi:10.1677/ ERC-08-0224)

Ronchi CL, Sbiera S, Leich E, Henzel K, Rosenwald A, Allolio B \& Fassnacht M 2013 Single nucleotide polymorphism array profiling of adrenocortical tumors-evidence for an adenoma carcinoma sequence? PLOS ONE 8 e73959. (doi:10.1371/journal.pone.0073959)

Ronchi CL, Kroiss M, Sbiera S, Deutschbein T \& Fassnacht M 2014a EJE PRIZE 2014 Current and evolving treatment options in adrenocortical carcinoma: where do we stand and where do we want to go? European Journal of Endocrinology 171 R1-R11. (doi:10.1530/EJE-14-0273)

Ronchi CL, Sbiera S, Volante M, Steinhauer S, Scott-Wild V, Altieri B, Kroiss M, Bala M, Papotti M, Deutschbein T et al. 2014b CYP2W1 is highly expressed in adrenal glands and is positively associated with the response to mitotane in adrenocortical carcinoma. PLOS ONE 9 e105855. (doi:10.1371/journal.pone.0105855)

Ross JS, Wang K, Rand JV, Gay L, Presta MJ, Sheehan CE, Ali SM, Elvin JA, Labrecque E, Hiemstra C et al. 2014 Next-generation sequencing of adrenocortical carcinoma reveals new routes to targeted therapies. Journal of Clinical Pathology 67 968-973. (doi:10.1136/jclinpath-2014202514)

Sabolch A, Feng M, Griffith K, Hammer G, Doherty G \& Ben-Josef E 2011 Adjuvant and definitive radiotherapy for adrenocortical carcinoma. International Journal of Radiation Oncology, Biology, Physics $\mathbf{8 0}$ 1477-1484. (doi:10.1016/j.ijrobp.2010.04.030)

Samnotra V, Vassilopoulou-Sellin R, Fojo AT, Oh WK, LaRocca RV, Ernstoff MS, Memoli VA, Cole BF, Quinn DI, Simmons PA et al. 2007 A phase II trial of gefitinib monotherapy in patients with unresectable adrenocortical carcinoma (ACC). Journal of Clinical Oncology 25 (18 Suppl) 15527. (available at: http://meeting.ascopubs.org/cgi/content/short/ 25/18_suppl/15527)

Sangoi AR, Fujiwara M, West RB, Montgomery KD, Bonventre JV, Higgins JP, Rouse RV, Gokden N \& McKenney JK 2011 Immunohistochemical distinction of primary adrenal cortical lesions from metastatic clear cell renal cell carcinoma: a study of 248 cases. American Journal of Surgical Pathology 35 678-686. (doi:10.1097/PAS. Ob013e3182152629)

Sasano H, Suzuki T, Shizawa S, Kato K \& Nagura H 1994 Transforming growth factor alpha, epidermal growth factor, and epidermal growth factor receptor expression in normal and diseased human adrenal cortex by immunohistochemistry and in situ hybridization. Modern Pathology 7 741-746.

Sbiera S, Schmull S, Assie G, Voelker HU, Kraus L, Beyer M, Ragazzon B, Beuschlein F, Willenberg HS, Hahner S et al. 2010 High diagnostic and prognostic value of steroidogenic factor-1 expression in adrenal tumors. Journal of Clinical Endocrinology and Metabolism 95 E161-E171. (doi:10.1210/jc.2010-0653)

Sbiera S, Leich E, Liebisch G, Sbiera I, Schirbel A, Wiemer L, Matysik S, Eckhardt C, Gardill F, Gehl A et al. 2015 Mitotane inhibits Sterol-O-Acyl Transferase 1 triggering lipid-mediated endoplasmic reticulum stress and apoptosis in adrenocortical carcinoma cells. Endocrinology 156 3895-3908. (doi:10.1210/en.2015-1367)

Schmitt A, Saremaslani P, Schmid S, Rousson V, Montani M, Schmid DM, Heitz PU, Komminoth P \& Perren A 2006 IGFII and MIB1 immunohistochemistry is helpful for the differentiation of benign from malignant adrenocortical tumours. Histopathology 49 298-307.

Schmitz KJ, Helwig J, Bertram S, Sheu SY, Suttorp AC, Seggewiss J, Willscher E, Walz MK, Worm K \& Schmid KW 2011 Differential expression of microRNA-675, microRNA-139-3p and microRNA-335 in benign and malignant adrenocortical tumours. Journal of Clinical Pathology 64 529-535. (doi:10.1136/jcp.2010.085621)

Schulick RD \& Brennan MF 1999 Long-term survival after complete resection and repeat resection in patients with adrenocortical carcinoma. Annals of Surgical Oncology 6 719-726. (doi:10.1007/s10434-9990719-7)

Sidhu S, Marsh DJ, Theodosopoulos G, Philips J, Bambach CP, Campbell P, Magarey CJ, Russell CF, Schulte KM, Roher HD et al. 2002 Comparative genomic hybridization analysis of adrenocortical tumors. Journal of Clinical Endocrinology and Metabolism 87 3467-3474. (doi:10.1210/ jcem.87.7.8697)

Sidhu S, Martin E, Gicquel C, Melki J, Clark SJ, Campbell P, Magarey CJ, Schulte KM, Roher HD, Delbridge L et al. 2005 Mutation and methylation analysis of TP53 in adrenal carcinogenesis. European Journal of Surgical Oncology 31 549-554. (doi:10.1016/j.ejso. 2005.01.013)

Slater EP, Diehl SM, Langer P, Samans B, Ramaswamy A, Zielke A \& Bartsch DK 2006 Analysis by cDNA microarrays of gene expression patterns of human adrenocortical tumors. European Journal of Endocrinology 154 587-598. (doi:10.1530/eje.1.02116)

Song G, Joe BN, Yeh BM, Meng MV, Westphalen AC \& Coakley FV 2011 Risk of catecholamine crisis in patients undergoing resection of unsuspected pheochromocytoma. International Brazilian Journal of Urology 37 35-40; discussion 40-31. (doi:10.1590/S1677-55382011 000100005) 
Soon PSH, Gil AJ, Benn DE, Clarkson A, Robinson BG, McDonald KL \& Sidhu SB 2009a Microarray gene expression and immunohistochemistry analyses of adrenocortical tumors identify IGF2 and Ki-67 as useful in differentiating carcinomas from adenomas. Endocrine-Related Cancer 16 573-583. (doi:10.1677/ERC-08-0237)

Soon PSH, Tacon LJ, Gill AJ, Bambach CP, Sywak MS, Campbell PR, Yeh MW, Wong SG, Clifton-Bligh RJ, Robinson BG et al. 2009b miR-195 and miR-483-5p Identified as Predictors of Poor Prognosis in Adrenocortical Cancer. Clinical Cancer Research 15 7684-7692. (doi:10.1158/ 1078-0432.CCR-09-1587)

Steenman M, Westerveld A \& Mannens M 2000 Genetics of BeckwithWiedemann syndrome-associated tumors: common genetic pathways. Genes Chromosomes and Cancer 28 1-13. (doi:10.1002/(SICI)10982264(200005)28:1<1::AID-GCC1> 3.0.CO;2-)

Stephan EA, Chung TH, Grant CS, Kim S, Von Hoff DD, Trent JM \& Demeure MJ 2008 Adrenocortical carcinoma survival rates correlated to genomic copy number variants. Molecular Cancer Therapeutics $\mathbf{7}$ 425-431. (doi:10.1158/1535-7163.MCT-07-0267)

Stommel JM, Kimmelman AC, Ying H, Nabioullin R, Ponugoti AH, Wiedemeyer R, Stegh AH, Bradner JE, Ligon KL, Brennan C et al. 2007 Coactivation of receptor tyrosine kinases affects the response of tumor cells to targeted therapies. Science 318 287-290. (doi:10.1126/science. 1142946)

Sturgeon C, Shen WT, Clark OH, Duh QY \& Kebebew E 2006 Risk assessment in 457 adrenal cortical carcinomas: How much does tumor size predict the likelihood of malignancy? Journal of the American College of Surgeons 202 423-430. (doi:10.1016/j.jamcollsurg.2005.11.005)

Suh I, Weng J, Fernandez-Ranvier G, Shen WT, Duh QY, Clark OH \& Kebebew E 2010 Antineoplastic effects of decitabine, an inhibitor of DNA promoter methylation, in adrenocortical carcinoma cells. Archives of Surgery 145 226-232. (doi:10.1001/archsurg.2009.292)

Szabo DR, Luconi M, Szabo PM, Toth M, Szucs N, Horanyi J, Nagy Z, Mannelli M, Patocs A, Racz K et al. 2014 Analysis of circulating microRNAs in adrenocortical tumors. Laboratory Investigation 94 331-339. (doi:10.1038/labinvest.2013.148)

Takazawa R, Ajima J, Yamauchi A \& Goto M 2004 Unusual double primary neoplasia: Adrenocortical and ureteral carcinomas in Werner syndrome. Urologia Internationalis 72 168-170. (doi:10.1159/000075974)

Takeuchi S, Balachandran A, Habra MA, Phan AT, Bassett RL Jr, Macapinlac HA \& Chuang HH 2014 Impact of (1)(8)F-FDG PET/CT on the management of adrenocortical carcinoma: analysis of 106 patients. European Journal of Nuclear Medicine and Molecular Imaging $\mathbf{4 1}$ 2066-2073. (doi:10.1007/s00259-014-2834-3)

Terzolo M, Boccuzzi A, Bovio S, Cappia S, De Giuli P, Ali A, Paccotti P, Porpiglia F, Fontana D \& Angeli A 2001 Immunohistochemical assessment of Ki-67 in the differential diagnosis of adrenocortical tumors. Urology 57 176-182.

Terzolo M, Angeli A, Fassnacht M, Daffara F, Tauchmanova L, Conton PA, Rossetto R, Buci L, Sperone P, Grossrubatscher E et al. 2007 Adjuvant mitotane treatment for adrenocortical carcinoma. New England Journal of Medicine 356 2372-2380.

Terzolo M \& Berruti A 2008 Adjunctive treatment of adrenocortical carcinoma. Current Opinion in Endocrinology, Diabetes and Obesity 15 221-226. (doi:10.1097/MED.0b013e3282fdf4c0)

Terzolo M, Ardito A, Zaggia B, Laino F, Germano A, De Francia S, Daffara F \& Berruti A 2012 Management of adjuvant mitotane therapy following resection of adrenal cancer. Endocrine 42 521-525. (doi:10.1007/ s12020-012-9719-7)

Terzolo M, Baudin AE, Ardito A, Kroiss M, Leboulleux S, Daffara F, Perotti P, Feelders RA, deVries JH, Zaggia B et al. 2013 Mitotane levels predict the outcome of patients with adrenocortical carcinoma treated adjuvantly following radical resection. European Journal of Endocrinology 169 263-270. (doi:10.1530/EJE-13-0242)

Tissier F, Louvel A, Grabar S, Hagnere AM, Bertherat J, Vacher-Lavenu MC, Dousset B, Chapuis Y, Bertagna X \& Gicquel C 2004 Cyclin E correlates with malignancy and adverse prognosis in adrenocortical tumors.
European Journal of Endocrinology 150 809-817. (doi:10.1530/eje.0. 1500809)

Tissier F, Cavard C, Groussin L, Perlemoine K, Fumey G, Hagnere AM, Rene-Corail F, Jullian E, Gicquel C, Bertagna X et al. 2005 Mutations of beta-catenin in adrenocortical tumors: Activation of the wnt signaling pathway is a frequent event in both benign and malignant adrenocortical tumors. Cancer Research 65 7622-7627. (doi:10.1158/ 0008-5472.CAN-05-0593)

Tissier F, Aubert S, Leteurtre E, Al Ghuzlan A, Patey M, Decaussin M, Doucet L, Gobet F, Hoang C, Mazerolles C et al. 2012 Adrenocortical Tumors: Improving the Practice of the Weiss System Through Virtual Microscopy A National Program of the French Network INCa-COMETE. American Journal of Surgical Pathology 36 1194-1201. (doi:10.1097/PAS. Ob013e31825a6308)

Tombol Z, Szabo PM, Molnar V, Wiener Z, Tolgyesi G, Horanyi J, Riesz P, Reismann P, Patocs A, Liko I et al. 2009 Integrative molecular bioinformatics study of human adrenocortical tumors: microRNA, tissue-specific target prediction, and pathway analysis. EndocrineRelated Cancer 16 895-906. (doi:10.1677/ERC-09-0096)

Touitou Y, Bogdan A \& Luton JP 1978 Changes in corticosteroid synthesis of the human adrenal cortex in vitro, induced by treatment with $\mathrm{o}, \mathrm{p}^{\prime}$-DDD for Cushing's syndrome: evidence for the sites of action of the drug. Journal of Steroid Biochemistry 9 1217-1224. (doi:10.1016/ 0022-4731(78)90015-8)

Toyota M, Ahuja N, Ohe-Toyota M, Herman JG, Baylin SB \& Issa JP 1999 CpG island methylator phenotype in colorectal cancer. PNAS 96 8681-8686. (doi:10.1073/pnas.96.15.8681)

van Erp NP, Guchelaar HJ, Ploeger BA, Romijn JA, den Hartigh J \& Gelderblom H 2011 Mitotane has a strong and a durable inducing effect on CYP3A4 activity. European Journal of Endocrinology 164 621-626. (doi:10.1530/EJE-10-0956)

van Koetsveld PM, Vitale G, Feelders RA, Waaijers M, Sprij-Mooij DM, de Krijger RR, Speel EJM, Hofland J, Lamberts SWJ, de Herder WW et al. 2013 Interferon-beta is a potent inhibitor of cell growth and cortisol production in vitro and sensitizes human adrenocortical carcinoma cells to mitotane. Endocrine-Related Cancer 20 443-454. (doi:10.1530/ERC12-0217)

Vargas MP, Vargas HI, Kleiner DE \& Merino MJ 1997 Adrenocortical neoplasms: role of prognostic markers MIB-1, P53, and RB. American Journal of Surgical Pathology 21 556-562.

Varley JM, McGown G, Thorncroft M, James LA, Margison GP, Forster G, Evans DG, Harris M, Kelsey AM \& Birch JM 1999 Are there lowpenetrance TP53 Alleles? evidence from childhood adrenocortical tumors American Journal of Human Genetics 65 995-1006. (doi:10.1086/ 302575)

Vassilopoulou-Sellin R, Guinee VF, Klein MJ, Taylor SH, Hess KR, Schultz PN \& Samaan NA 1993 Impact of adjuvant mitotane on the clinical course of patients with adrenocortical cancer. Cancer 71 3119-3123.

Velazquez-Fernandez D, Laurell C, Geli J, Hoog A, Odeberg J, Kjellman M, Lundeberg J, Hamberger B, Nilsson P \& Backdahl M 2005 Expression profiling of adrenocortical neoplasms suggests a molecular signature of malignancy. Surgery 138 1087-1094. (doi:10.1016/j.surg.2005.09.031)

Venkatesh S, Hickey RC, Sellin RV, Fernandez JF \& Samaan NA 1989 Adrenal cortical carcinoma. Cancer 64 765-769.

Volante M, Bollito E, Sperone P, Tavaglione V, Daffara F, Porpiglia F, Terzolo M, Berruti A \& Papotti M 2009 Clinicopathological study of a series of 92 adrenocortical carcinomas: from a proposal of simplified diagnostic algorithm to prognostic stratification. Histopathology $\mathbf{5 5}$ 535-543. (doi:10.1111/j.1365-2559.2009.03423.x)

Volante M, Terzolo M, Fassnacht M, Rapa I, Germano A, Sbiera S, Daffara F, Sperone P, Scagliotti G, Allolio B et al. 2012 Ribonucleotide Reductase Large Subunit (RRM1) Gene Expression May Predict Efficacy of Adjuvant Mitotane in Adrenocortical Cancer. Clinical Cancer Research 18 3452-3461. (doi:10.1158/1078-0432.CCR-11-2692)

Wachenfeld C, Beuschlein F, Zwermann O, Mora P, Fassnacht M, Allolio B $\&$ Reincke M 2001 Discerning malignancy in adrenocortical tumors:

Published by Bioscientifica Ltd 
are molecular markers useful? European Journal of Endocrinology 145 335-341.

Wagner J, Portwine C, Rabin K, Leclerc JM, Narod SA \& Malkin D 1994 High frequency of germline p53 mutations in childhood adrenocortical cancer. Journal of National Cancer Institute 86 1707-1710. (doi:10.1093/ jnci/86.22.1707)

Wagner AS, Fleitz JM \& Kleinschmidt-DeMasters BK 2005 Pediatric adrenal cortical carcinoma: brain metastases and relationship to NF-1, case reports and review of the literature. Journal of Neuro-Oncology 75 127-133. (doi:10.1007/s11060-005-0376-z)

Waldmann J, Bartsch DK, Kann PH, Fendrich V, Rothmund M \& Langer P 2007 Adrenal involvement in multiple endocrine neoplasia type 1: results of 7 years prospective screening. Langenbeck's Archives of Surgery 392 437-443. (doi:10.1007/s00423-006-0124-7)

Wan X, Harkavy B, Shen N, Grohar P \& Helman LJ 2007 Rapamycin induces feedback activation of Akt signaling through an IGF-1R-dependent mechanism. Oncogene 26 1932-1940. (doi:10.1038/sj.onc.1209990)

Wang C, Sun Y, Wu H, Zhao D \& Chen J 2014 Distinguishing adrenal cortical carcinomas and adenomas: a study of clinicopathological features and biomarkers. Histopathology 64 567-576.

Wasserman JD, Zambetti GP \& Malkin D 2012 Towards an understanding of the role of p53 in adrenocortical carcinogenesis. Molecular and Cellular Endocrinology 351 101-110. (doi:10.1016/j.mce.2011.09.010)

Weber MM, Auernhammer CJ, Kiess W \& Engelhardt D 1997 Insulin-like growth factor receptors in normal and tumorous adult human adrenocortical glands. European Journal of Endocrinology 136 296-303. (doi:10.1530/eje.0.1360296)

Weiss LM 1984 Comparative histologic study of 43 metastasizing and nonmetastasizing adrenocortical tumors. American Journal of Surgical Pathology 8 163-169. (doi:10.1097/00000478-198403000-00001)

Weiss LM, Medeiros LJ \& Vickery AL Jr 1989 Pathologic features of prognostic significance in adrenocortical carcinoma. American Journal of Surgical Pathology 13 202-206. (doi:10.1097/00000478198903000-00004)

Wiedemann HR 1983 Tumors and Hemihypertrophy Associated with Wiedemann-Beckwith Syndrome. European Journal of Pediatrics 141 129. (doi:10.1007/BF00496807)

Williamson SK, Lew D, Miller GJ, Balcerzak SP, Baker LH \& Crawford ED 2000 Phase II evaluation of cisplatin and etoposide followed by mitotane at disease progression in patients with locally advanced or metastatic adrenocortical carcinoma: a Southwest Oncology Group Study. Cancer 88 1159-1165.

Wong DD, Spagnolo DV, Bisceglia M, Havlat M, McCallum D \& Platten MA 2011 Oncocytic adrenocortical neoplasms-a clinicopathologic study of 13 new cases emphasizing the importance of their recognition. Human Pathology 42 489-499. (doi:10.1016/j.humpath.2010.08.010)

Wortmann S, Quinkler M, Ritter C, Kroiss M, Johanssen S, Hahner S, Allolio B \& Fassnacht M 2010 Bevacizumab plus capecitabine as a salvage therapy in advanced adrenocortical carcinoma. European Journal of Endocrinology 162 349-356. (doi:10.1530/EJE-09-0804)

Xu YZ, Zhu Y, Shen ZJ, Sheng JY, He HC, Ma G, Qi YC, Zhao JP, Wu YX, Rui WB et al. 2011 Significance of heparanase-1 and vascular endothelial growth factor in adrenocortical carcinoma angiogenesis: potential for therapy. Endocrine 40 445-451. (doi:10.1007/s12020-0119502-1)

Zacharieva S, Atanassova I, Orbetzova M, Nachev E, Kalinov K, Kirilov G, Shigarminova R, Ivanova R \& Dashev G 2004 Circulating vascular endothelial growth factor and active renin concentrations and prostaglandin E2 urinary excretion in patients with adrenal tumours. European Journal of Endocrinology 150 345-349. (doi:10.1530/eje.0. 1500345)

Zettinig G, Mitterhauser M, Wadsak W, Becherer A, Pirich C, Vierhapper H, Niederle B, Dudczak R \& Kletter K 2004 Positron emission tomography imaging of adrenal masses: F-18-fluorodeoxyglucose and the 11 betahydroxylase tracer C-11-metomidate. European Journal of Nuclear Medicine and Molecular Imaging 31 1224-1230. (doi:10.1007/s00259004-1575-0)

Zhang HM, Perrier ND, Grubbs EG, Sircar K, Ye ZX, Lee JE \& Ng CS 2012 CT features and quantification of the characteristics of adrenocortical carcinomas on unenhanced and contrast-enhanced studies. Clinical Radiology 67 38-46. (doi:10.1016/j.crad.2011.03.023)

Zhao JM, Speel EJM, Muletta-Feurer S, Rutimann K, Saremaslani P, Roth J, Heitz PU \& Komminoth P 1999 Analysis of genomic alterations in sporadic adrenocortical lesions - Gain of chromosome 17 is an early event in adrenocortical tumorigenesis. American Journal of Pathology 155 1039-1045. (doi:10.1016/S0002-9440(10)65205-4)

Zhao J, Roth J, Bode-Lesniewska B, Pfaltz M, Heitz PU \& Komminoth P 2002 Combined comparative genomic hybridization and genomic microarray for detection of gene amplifications in pulmonary artery intimal sarcomas and adrenocortical tumors. Genes Chromosomes and Cancer 34 48-57. (doi:10.1002/gcc.10035)

Received in final form 12 October 2015

Accepted 15 October 2015

Made available online as an Accepted Preprint

16 October 2015
(C) 2016 Society for Endocrinology Printed in Great Britain 